\title{
Menggali Minangkabau dalam film dengan mise-en-scene
}

\author{
Herry Nur Hidayat ${ }^{1}$, Bani Sudardi ${ }^{2}$, Sahid Teguh Widodo ${ }^{3}$, Sri K Habsari ${ }^{4}$ \\ ${ }^{1}$ Universitas Andalas, Padang, Indonesia \\ ${ }^{2,3,4}$ Universitas Sebelas Maret, Surakarta, Indonesia
}

\begin{abstract}
ABSTRAK
Sejarah perkembangan industri perfilman Indonesia tidak bisa melepaskan diri dari muatan lokalitas sebagai sumber penciptaan. Sebagai salah satu etnik di Indonesia, Minangkabau diketahui telah menjadi sumber penciptaan film, bahkan sejak awal pertumbuhan industri film di Indonesia. Oleh karena beragamnya unsur keminangkabauan, tidak mudah menampilkan unsur-unsur keminangkabauan yang telah dikenal khalayak penonton. Akan tetapi, kajian sebelumnya terhadap muatan keminangkabauan dalam film seolah mengabaikan citraan visual (visual image) ini. Melalui pendekatan mise-en-scene, artikel ini menguraikan unsur-unsur keminangkabauan yang ditampilkan dalam film, baik visual maupun unsur naratifnya. Di samping itu, artikel ini juga mencoba menjawab beragam kritik etnisitas atas film bermuatan Minangkabau. Analisis difokuskan pada citraan visual unsur keminangkabauan yang berhubungan dengan tokoh dan latar sebagai pembangun aspek naratif dalam tujuh film terpilih. Hasil analisis menunjukkan bahwa citraan visual ikon-ikon Minangkabau tampak mendominasi unsur keminangkabauan dalam film, yaitu rumah gadang, rangkiang, dan pakaian. Ikon visual tersebut muncul dalam bentuk desain pelataran dan propertinya. Beberapa adegan yang menampilkan rumah gadang menunjukkan pula peran dan kedudukan mamak rumah dalam sistem kekerabatan serta representasi demokrasi di Minangkabau. Tampaknya, aspek visual unsur keminangkabauan tersebut ditampilkan untuk memperkuat latar tempat dan sosial sebagai sarana penceritaan. Di samping itu, dapat pula disampaikan bahwa tampilnya unsur keminangkabauan tidak secara mutlak menggambarkan Minangkabau.
\end{abstract}

Kata-kata Kunci: Minangkabau; film; mise-en-scene; visual; naratif

\section{Capturing Minangkabau in the movie through mise-en-scene}

\begin{abstract}
Indonesian film industry's history cannot avoid locality as a source of creation. As one of Indonesia's ethnic groups, Minangkabau is known as the source of film creation, even since the early days of Indonesia's film growth. Due to the various Minangkabau elements, it is not easy to present its aspects to the audience as a kind of representation. This article explored and described the Minangkabau features displayed in the film through a mise-en-scene approach, both visually and narrative elements. Apart from that, this article also tried to answer various ethnic criticisms for Minangkabau films. This article focused on the Minangkabau elements visual imagery related to the characters and settings as the builders of several selected films' narrative aspects. The results showed that Minangkabau icons' graphical images dominated the Minangkabau elements in the movie, namely 'Rumah Gadang', 'Rangkiang', and clothes. This visual icon appeared as a setting and displayed in the set design and its properties. Several scenes featuring the 'Rumah Gadang' also showed the role and position of the 'Mamak Rumah' in the kinship system and the representation of democracy in Minangkabau. It seemed that Minangkabau's elements'visual aspect was presented to strengthen the setting as a means of storytelling. In other words, the appearance of the component did not necessarily describe Minangkabau.
\end{abstract}

Keywords: Minangkabau; film; mise-en-scene; visual; narative

Korespondensi: Herry Nur Hidayat, S.S., M.Hum. Universitas Andalas. Kampus Unand Limau Manis Padang 25163.Email: herrynh@hum.unand.ac.id 


\section{PENDAHULUAN}

Minangkabau adalah salah satu suku besar di Indonesia yang tidak hanya satu atau dua kali diangkat dalam film. Selain menampilkan keindahan alam, tradisi dan folklor merupakan subjek yang banyak diangkat dalam film. Berdasarkan catatan hasil penelusuran penulis, hingga saat ini (1926 - 2018) terdapat lebih dari dua puluh judul film Indonesia yang mengangkat keminangkabauan. Catatan ini tidak menghitung film-film independen yang dibuat oleh lembaga atau komunitas.

Film Indonesia dengan muatan keminangkabauan pertama adalah Melati Van Agam (1930). Film ini dibuat dalam dua bagian (Melati Van Agam I dan II) yang masih dalam format film bisu. Film Melati Van Agam ini diproduksi oleh Tan's Film dan diangkat dari novel karya Parada Harahap dengan judul yang sama. Isi cerita layaknya cerita Romeo Juliet tetapi berlatar Sumatera Barat. Hoay (1930) dalam kritiknya terhadap film ini menyebutkan bahwa film ini mengubah cerita novel yang hambar menjadi film yang baik, rapi, dan menarik perhatian penonton. Selanjutnya, kisah fenomenal roman (novel) Siti Nurbaya karya Marah Rusli juga diangkat menjadi film pada tahun 1941. Oleh Kristanto (2007), film ini disebut sebagai versi film pertama novel Siti Nurbaya. Akan tetapi, kedua film ini seolah diabaikan dalam pembicaraan film bermuatan keminangkabauan. Hal ini diduga karena tidak ditemukannya kembali film ini untuk digunakan sebagai bahan kajian. Menurut Heider (1991), sulit menyusun sejarah perfilman Indonesia karena banyak film yang tidak lagi bisa ditemukan, terutama film-film yang dibuat sebelum tahun 1950. Oleh sebab itu, tidak mengherankan jika film yang diyakini mengandung muatan keminangkabauan pertama adalah Harimau Tjampa (1953) yang disutradarai oleh R. Djajakusuma karena masih bisa ditemukan dan telah dialih wahana menjadi bentuk digital oleh Sinematek Indonesia (Kamal, 2013). Mengedepankan aksi laga dan filosofi silek (silat Minangkabau), film ini meraih penghargaan FFI 1955 sebagai film dengan skenario terbaik.

Sebagai sumber penciptaan, cukup banyak karya sastra bermuatan Minangkabau yang diangkat menjadi film. Selain adaptasi terhadap novel Melati van Agam dan Siti Noerbaja, tahun 1972 Asrul Sani mengangkat kisah roman Salah Asuhan menjadi film dengan judul yang sama. Pamusuk Eneste (Eneste, 1991) menyebut perbedaan novel dan film Salah Asuhan ini sebagai bentuk ekranisasi dan termasuk dalam perubahan bervariasi. Sementara itu, Heider (1991) menyebut film Salah Asuhan ini adalah bentuk kritik rasialisme dan diskriminasi sosial pada masa Kolonial Belanda. 
Film hasil adaptasi yang mengandung muatan Minangkabau yang termutakhir adalah Tenggelamnya Kapal van der Wicjk. Film ini diangkat dari novel Hamka yang juga berjudul Tenggelamnya Kapal van der Wicjk. Film ini dianggap sebagai fenomena yang cukup mencolok dalam perfilman Indonesia. Beberapa kritik terhadapnya mengungkapkan bahwa film ini adalah puncak visualisasi keminangkabauan dalam era tahun 2010-an. Meskipun terdapat beberapa perbedaan layaknya sebuah ekranisasi, melalui sinematografi, musik, akting, dan pemilihan latar, film ini seolah mencoba memaksimalkan adaptasi terhadap cerita novel karya Hamka ini (Musyafir dkk., 2017). Melalui strukturnya, Tenggelamnya Kapal van der Wijck menampilkan identitas budaya nasional Indonesia (Thalib, 2017) sekaligus budaya matrilineal Minangkabau (Trisnawati \& Yesicha, 2018).

Selain dari karya sastra dan latar alam, sumber keminangkabauan yang diangkat menjadi film juga diangkat dari cerita rakyat, mitos, tradisi, dan tatanan sosial masyarakat Minangkabau. Pada tahun 2009, dirilislah Merantau (2009) yang menjadi salah satu film fenomenal dalam sejarah perfilman Indonesia. Film yang dibintangi Iko Uwais ini dianggap sebagai tonggak kebangkitan film laga Indonesia. Di samping itu, film ini juga menandai kembali diperhitungkannya muatan tradisi lokalitas tradisional, khususnya Minangkabau, sebagai sumber penciptaan film setelah masa-masa suram industri perfilman Indonesia. Terlepas dari adanya kritik terhadap film ini (Indah, 2009), tidak bisa dipungkiri bahwa Merantau mengangkat unsur keminangkabauan. Dengan alur cerita yang sederhana, film Merantau merangkai peristiwa keseharian dengan menyisipkan muatan lokalitas yaitu silek dan merantau (Ica, 2009; Miawruu, 2009).

Cerita rakyat dan mitos Minangkabau juga muncul menjadi film Malin Kundang Anak Durhaka (1971), 7 Manusia Harimau (1986), dan Palasik (2015). Perjuangan rakyat Minangkabau melawan kekuasaan kolonial Belanda ditampilkan dalam Para Perintis Kemerdekaan (1977). Profil perantau dan keturunan perantau Minangkabau pada era modern muncul dalam Cinta Tapi Beda (2012), Tabula Rasa (2014), Surga di Telapak Kaki Ibu (2016), dan Me vs Mami (2016). Konflik adat dalam proses perkawinan di Minangkabau muncul dalam Liam dan Laila (2018).

Keragaman muatan keminangkabauan dalam sejarah perfilman Indonesia secara tidak langsung menunjukkan kekayaan lokalitas sebagai sumber penciptaan film. Pengetahuan tentang keminangkabauan pada akhirnya tidak cukup menjadi bekal penciptaan film bermuatan Minangkabau. Penguasaan teknik dan kreativitas menjadi faktor penting bagi 
seniman film untuk merepresentasikan muatan lokal khususnya Minangkabau.

Film merupakan media yang sangat efektif untuk menyampaikan pesan atau sebagai sarana komunikasi karena memiliki banyak penonton atau penikmat. Film juga merupakan media yang lengkap karena dilengkapi dengan ilustrasi gambar bergerak dan suara. Pesan yang disampaikan dalam film berbentuk kisah atau cerita menjadi sarana bagi suatu lembaga untuk menyebarluaskan suatu pesan atau informasi (Sutorini dkk., 2019). Film sebagai salah satu media massa yang menjadi saluran berbagai macam gagasan dan konsep yang dapat memunculkan dampak tertentu dari penayangannya. Oleh karenanya, film adalah salah satu alat untuk menghadirkan realitas sosial yang direpresentasikan sebagai realitas media (Roberts, 1998). Realitas media yang dibangun oleh film merupakan hasil pemikiran para pembuat film, yang di dalam pengembangannya mengikuti tututan pasar (Yasmin dkk., 2017).

Seperti halnya karya sastra yang menggunakan bahasa sebagai mediumnya, film menggunakan "kosakata" dan struktur khusus berupa komposisi, desain visual, pencahayaan, kontrol gambar, keberlanjutan, pergerakan, dan sudut pandang (Brown, 2012). Mencoba mengenal film tidak bisa lepas dari pengetahuan akan bahasa film ini oleh karena film biasa juga disebut cerita visual (visual storytelling). Tentu saja, konsepnya tidak jauh dari teknik-teknik pengolahan visual atau sinematografi.

Memang tidak mudah untuk menampilkan representasi Minangkabau dalam film. Hal ini bukan hanya terbatas pada konteks ekranisasi saja, melainkan juga representasi Minangkabau pada umumnya. Pengetahuan penonton tentang keminangkabauan tidak akan mudah dikelabui hanya dengan aspek visual ikonik. Pengetahuan kreator film tentang keminangkabauan, sebagai bagian proses resepsi dalam adaptasi, harus juga mempertimbangkan pengetahuan calon penonton dalam proses produksi film.

Film bermuatan lokalitas Minangkabau bukan tidak pernah menjadi pembicaraan dan polemik. Film Titian Serambut Dibelah Tujuh (1982) yang disutradarai Chaerul Umam menjadi perbincangan hangat oleh karena latar tempat dan sosial Minangkabau yang diangkat. Di samping menjadi diskusi sebagai model dan contoh formal film Islami (Heeren, 2012), film ini menuai kritik dan protes karena membuka perilaku seksual yang menyimpang dalam kehidupan masyarakat Minangkabau (Arief, 2016). Cinta Tapi Beda (2012) garapan Hanung Bramantyo menjadi pembicaraan karena dianggap menghina Minangkabau, Jawa, bahkan Islam. Film ini menceritakan tokoh Diana, asal Padang dan beragama Katolik, dengan Cahyo, asal Yogyakarta beragama Islam. Diceritakan 
lika-liku hubungan mereka yang berbeda keyakinan. Namun, khalayak cenderung tidak menerima isi cerita film tersebut. Penonton menuduhfilm ini mendiskreditkan Minangkabau dengan pernyataan "Minangkabau adalah Islam". Hanung sebagai sutradara akhirnya memutuskan untuk menghentikan pemutaran film tersebut (Noviandi, 2013). Bahkan, pada tahun 2018 lalu, film ini dituntut ke ranah hukum (Priyambodo, 2018).

Artikel ini secara singkat memaparkan muatan keminangkabauan dalam film melalui pendekatan mise-en-scene, yaitu melihat tampilan visual sebagai wujud hasil produksi. Pendekatan ini merupakan bentuk analisis formal terhadap unsur-unsur naratif dengan visualisasi keminangkabauan sebagai fokus kajian. Hal ini juga mempertimbangkan komposisi visual elemen mise-en-scene yang saling berhubungan dan turut berperan penting dalam membangun pemahaman terhadap tema cerita. Hasil analisis diharapkan dapat digunakan sebagai data penelitian selanjutnya terhadap muatan keminangkabauan dalam film. Di samping itu, kajian ini juga mencoba menjawab beragam kritik bernada etnisitas terhadap film-film bermuatan Minangkabau. Benarkah visualisasi Minangkabau dalam film menggambarkan identitas etnik Minangkabau?.

Tampilan visual sering dianggap sebagai bentuk representasi paling mudah dikenali dalam film oleh karena film merupakan bentuk cerita visual. Menurut Brown, tugas utama pembuat film adalah mencipta dunia visual. Dunia visual adalah bagian penting bagi penonton untuk dapat memahami cerita dan motivasi di dalamnya (Brown, 2012). Lewis menyebut aspek ini termasuk dalam mise-enscene (Lewis, 2014). Mise-en-scene mengacu pada semua elemen visual. Empat aspek miseen-scene adalah desain latar (setting), kostum, pencahayaan, dan pergerakan tokoh (Lathrop \& Sutton, 2013).

Dalam perkembangannya, pengertian mise-en-scene dipahami secara berbeda. Di satu pihak mise-en-scene dipahami sebagai bagian dari gaya (style) pembuat film. Di lain pihak, mise-en-scene dipahami sebagai tampilan sebagai hasil kreasi pembuat film. Mengingat aspek-aspek di dalam mise-en-scene ini, Misen-scene merupakan praktik estetik profesional dan sebagai teori atau pendekatan. Namun demikian, perlu ditekankan kembali bahwa mise-en-scene mengandung seluruh aspek gaya yaitu praproduksi dan pascaproduksi (Branigan \& Buckland, 2014).

Empat aspek mise-en-scene adalah desain latar (setting), kostum, pencahayaan, dan pergerakan tokoh (Lathrop \& Sutton, 2013). Pergerakan tokoh yang dimaksud adalah tampilan perpindahan atau posisi aktor dalam sebuah ruang kamera (frame) atau lebih dikenal 
dengan blocking (Lewis, 2014). Dalam hal ini, blocking melibatkan akting aktor dengan kamera. Blocking dapat berupa posisi statis atau pergerakan yang juga melibatkan ekspresi dan gestur aktor. Dalam hal ini, aktor bukan hanya dipandang sebagai desain visual dalam film melainkan sebagai elemen penting yang turut membangun pesan naratif dalam film (Lathrop \& Sutton, 2013).

Latar dan desainnya juga turut membangun interpretasi visual dan mendukung estetika pengadeganan (Sreekumar \& Vidyapeetham, 2015). Aspek mise-en-scene ini memainkan peran penting dalam membangun cerita. Hubungannya dengan tokoh dan peristiwa menjadikannya elemen yang perlu diperhitungkan dengan cermat terutama aspek artistik dan dramatik. Dalam hal ini, latar dapat merepresentasikan tempat dan suasana yang sama atau sebuah rekaan. Oleh karenanya, desain latar memerlukan pendukung yaitu properti (Lathrop \& Sutton, 2013; Lewis, 2014). Tidak jarang properti dalam film menjadi faktor penentu perubahan karakter bahkan jalan cerita dalam film. Properti dalam setting bukanlah sekadar pelengkap melainkan turut menentukan dan membangun keutuhan cerita. Dalam aspek latar ini juga terdapat elemen ruang (space) (Mochama, 2020). Elemen ini berhubungan dengan unsur sinematografi dalam membentuk ruang pelataran melalui tangkapan kamera.
Kostum dan tata rias juga merupakan elemen penting yang turut mendukung tema. Kostum dalam film harus sesuai dengan latar waktu, tempat, dan suasana. Di samping itu, kostum juga turut membangun karakter tokoh, misalnya status sosial tokoh atau usia tokoh (Lathrop \& Sutton, 2013; Lewis, 2014). Sama halnya dengan latar, dalam kostum juga kadang diperlukan properti. Tentunya, harus dibedakan properti latar dengan properti kostum. Kostum, tata rias, maupun propertinya, kesemuanya sangat berperan dalam keutuhan sebuah cerita.

Bagi sutradara, pencahayaan lebih dari sekadar penerangan. Seperti halnya aspek miseen-scene lainnya, pencahayaan membutuhkan pengetahuan dan keterampilan yang tidak mudah. Pencahayaan dalam proses produksi film akan turut membangun aspek-aspek naratif yang akan disaksikan penonton (Lathrop \& Sutton, 2013).

Desain pencahayaan dapat menciptakan atau menghilangkan bayangan. Inilah yang akan ditangkap kamera. Melalui pencahayaan, kamera dapat menangkap kegelapan untuk menciptakan kengerian, atau hanya sekadar pembeda waktu pagi, siang, sore, dan malam. Pencahayaan dapat membentuk kesan penonton kepada tokoh dan menciptakan suasana sebagai aspek penting dari bahasa visual film (Lewis, 2014).

Artikel ini membahas muatan 
keminangkabauan dalam film melalui aspekaspek mise-en-scene tersebut di atas. Namun demikian, visualisasi keminangkabauan yang muncul dalam film menjadi fokus kajian ini tidak terbatas pada ikon-ikon Minangkabau. Pengamatan juga dilakukan terhadap lakuan dan praktik sosial yang muncul secara visual.

\section{METODE PENELITIAN}

Berdasarkan pengamatan terhadap filmfilm bermuatan keminangkabauan, material sumber data dibatasi pada judul-judul film berikut: Harimau Tjampa (1953), Para Perintis Kemerdekaan (1977), Titian Serambut Dibelah Tujuh (1986), Di Bawah Lindungan Ka'bah (2011), Tenggelamnya Kapal van der Wijck (2013), Me vs Mami (2016), dan Liam dan Laila (2018). Film-film tersebut diasumsikan mengandung muatan keminangkabauan yang cukup intens. Di samping itu, tahun rilis dapat digunakan sebagai indikator era yang membawa semangat zaman yang berbeda, baik dalam konteks artistik maupun industri.

Metode yang digunakan dalam penelitian ini adalah metode deskriptif-kualitatif. Dalam hal ini, data primer dianalisis melalui interpretasi dan diperkuat oleh perbandingannya dengan data sekunder. Data primer adalah tekstual naratif dalam ruang lingkup film yang dihubungkan dengan material sumber data. kajian adalah aspek mise-en-scène yaitu latar (setting), kostum dan tata rias, pencahayaan, dan pergerakan tokoh. Unsur-unsur ini digunakan sebagai alat analisis untuk mengungkapkan visualisasi Minangkabau yang terkandung dalam film.

Perlu disampaikan di sini bahwa hasil penelusuran dan pengumpulan sumber data (1926-2018) diperoleh dua puluh empat judul film yang diasumsikan mengandung muatan keminangkabauan. Namun demikian, artikel ini hanya menampilkan analisis beberapa judul terpilih. Pilihan sumber data didasarkan pada terjangkaunya sumber data (beberapa judul tidak ditemukan), intensitas muatan keminangkabauan (berdasar pengamatan), dan penentuan film sebagai wakil atau semangat zaman (trend) perfilman Indonesia.

Adapun konsep unsur keminangkabauan di sini dibatasi pada unsur ikonik yang telah dikenal khalayak penonton, yaitu bangunan atau gedung sebagai bagian dari lanskap dan pakaian pemeran. Hal ini berhubungan dengan kecenderungan kritik etnisitas terhadap film Minangkabau berdasar tampilan ikonik tersebut. Proses validasi data tidak hanya dilakukan melalui pengamatan berulang tetapi juga melalui studi kepustakaan terhadap tulisan, artikel, resensi, dan pembicaraan tentang material sumber data sebagai data sekunder. 


\section{HASIL DAN PEMBAHASAN}

Telah disampaikan pada bagian sebelumnya, Harimau Tjampa dianggap sebagai film dengan muatan keminangkabauan pertama dalam sejarah perfilman Indonesia. Film ini diproduksi oleh PERFINI dan disutradarai D.

Djajakusuma. Film ini bercerita tentang tokoh Lukman yang merantau dan menuntut ilmu silek (silat) untuk membalas dendam kematian ayahnya yang dibunuh oleh Datuk Langit. Melalui berbagai peristiwa, akhirnya Lukman dapat menuntut balas dengan mengalahkan Datuk Langit dalam pertarungan silek. Filosofi bela diri silek sangat kental dalam film ini. Meskipun berlatar Minangkabau, film ini juga banyak menampilkan seni tradisi Melayu. Di samping silek, film ini juga menampilkan musik tradisional Minangkabau, adat, serta pepatah petitih.

Pada tahun 1977 Asrul Sani menyutradarai film Para Perintis Kemerdekaan yang diadaptasi dari novel karya Hamka Di Bawah Lindungan $K a ' b a h$. Film ini meraih penghargaan sebagai Film Terbaik pada FFI 1981. Dalam filmnya ini, Asrul Sani merombak cerita novel sebagai bentuk interpretasinya terhadap karya Hamka. Bisa dikatakan, kesetiaannya pada cerita novel hanya terbatas pada tokoh dan penokohan dalam cerita. Asrul Sani membangun alur melalui sudut pandang yang berbeda. Film ini mengangkat tema peran pergerakan Islam (di Minangkabau) dalam perjuangan kemerdekaan Indonesia. Dalam hal ini, Junus (1984) mengatakan, Asrul memperlakukan cerita novel menjadi film sesuai dengan penilaian kembali suasana masa lampau berdasarkan pemikiran masa kini, masa ia mengerjakan film.

Film Tenggelamnya Kapal van der Wijck dapat dikatakan sebagai puncak visualisasi keminangkabauan dalam film selama satu dekade terakhir. Film yang diangkat dari novel Hamka ini, melalui sinematografi maupun mise-en-scene, menunjukkan usaha maksimal menampilkan muatan Minangkabau. Meskipun ada perbedaan dengan novelnya, sebagai satu ciri bentuk ekranisasi, tema cerita novel cukup tersampaikan secara jelas dalam film ini. Film yang disutradarai Sunil Soraya ini tampil dalam latar waktu cerita tahun 1930-an sesuai dengan novelnya. Hubungan percintaan Zainuddin dengan Hayati yang terhalang adat Minangkabau ditampilkan melalui konflik antartokohnya.

Sebagai hasil ekranisasi, film Tenggelamnya Kapal van der Wijck menunjukkan beberapa bentuk perubahan. Musyafir, dkk. (2017) menyebut terdapat 82 aspek penciutan, 64 aspek penambahan, and 38 aspek perubahan bervariasi. Tampaknya, Musyafir, dkk. mengaplikasikan kajian ekranisasi yang dikemukakan oleh Pamusuk Eneste. Namun, dilihat dari aspek 
sinematografi, film Tenggelamnya Kapal van der Wijck memiliki beberapa keunggulan dalam mengungkapkan optimisme tokoh (Harahap, 2019).

Film Me vs Mami disutradarai Ody C Harahap dan dirilis tahun 2016. Film ini menampilkan muatan keminangkabauan melalui konflik antartokoh dalam konteks kehidupan keseharian. Berlatar dunia modern, film ini bercerita tentang perjalanan Maudy (Mami) dan anaknya, Mira, pulang ke kampung halaman suami Maudy di Payakumbuh, Sumatera Barat. Dalam perjalanan inilah muncul banyak konflik yang turut menampilkan visualisasi keminangkabauan.

Disebut terinspirasi dari kisah nyata, Liam dan Laila juga mewarnai perfilman Indonesia dengan muatan keminangkabauan. Film yang disutradarai Arief Malinmudo ini mengangkat konflik yang muncul dalam proses perjodohan dan perkawinan antarsuku bangsa dan agama, Minangkabau dengan Perancis. Laila adalah gadis Minangkabau berpendidikan tinggi yang terlanjur nyaman dengan status kesendiriannya, di samping karena keluarga kerabat yang sangat pemilih menentukan pasangannya. Tanpa sengaja, dia berkenalan dengan Liam pemuda asal Perancis melalui media sosial. Perkenalan ini akhirnya membawa Liam untuk datang ke ranah Minang. Konflik pun muncul saat Liam mengutarakan niat untuk mempersunting Laila.
Deskripsi singkat tiap-tiap film di atas menunjukkan bahwa konflik tokoh selalu menjadi pusat bangunan tema dan ide cerita Aksi tokoh dalam sebuah peristiwa secara tidak langsung membangun alur yang juga merupakan unsur utama cerita dan penceritaan. Dalam hal ini, di samping aspek visual, tokoh juga membawa indikator penanda keminangkabauan.

Selain bahasa yang digunakan, indikator yang dapat dengan mudah dikenali dalam film adalah visualisasi latar. Latar dalam hal aspek mise-en-scene bukan hanya menunjukkan tempat melainkan juga properti yang ada di dalam latar tersebut dan ruang (space) yang dibatasi oleh tangkapan kamera (frame).

Ikon tentang Minangkabau yang paling dikenal hingga saat ini adalah rumah gadang. Bahkan, pada tahun 1973 dan 1978 Bank Indonesia mencetak uang logam (koin) pecahan Rp100,00 bergambar rumah gadang. Rumah gadang adalah salah satu Warisan Budaya Tak Benda (WBTB) dari Sumatera Barat yang telah ditetapkan pada tahun 2013 . Karakteristik dan keunikan rumah gadang telah menarik banyak peneliti untuk mengkajinya. Menurut bentuknya, rumah gadang biasa juga disebut rumah gonjong atau rumah bagonjong (bergonjong) oleh karena bentuk atapnya yang runcing menjulang (Navis, 1984). 


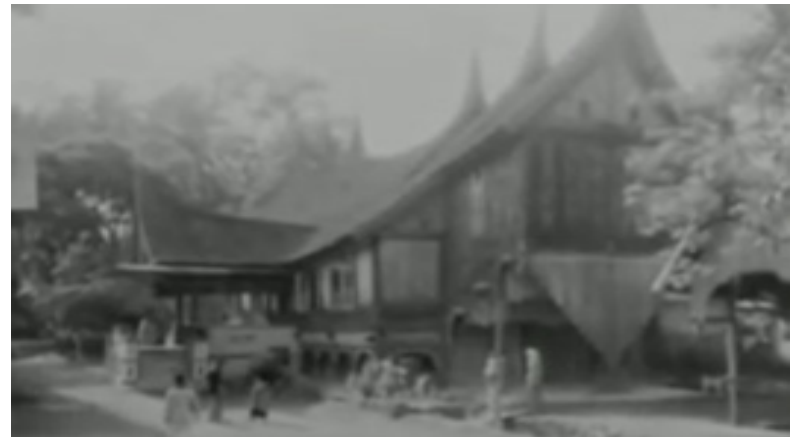

Sumber: tangkapan layar film Harimau Tjampa (1953)

Gambar 1 Rumah gadang dalam Harimau Tjampa

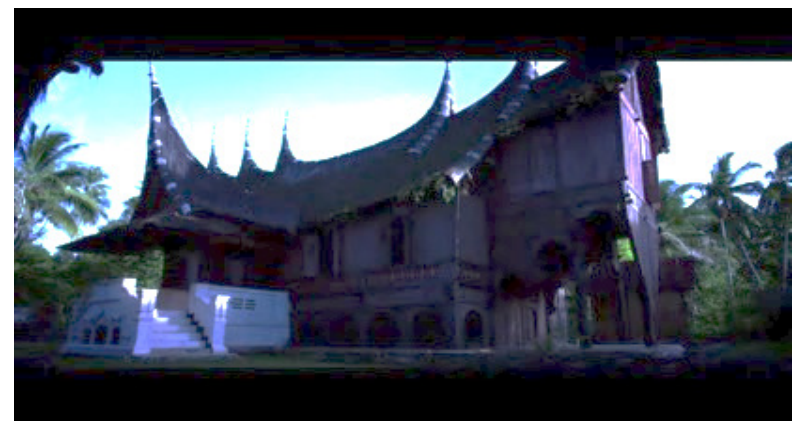

Sumber: tangkapan layar film Tenggelamnya Kapal van Der Wijck (2013)

\section{Gambar 2 Rumah gadang dalam Tenggelamnya Kapal van Der Wijck}

Bangunan rumah gadang ini sekaligus adalah ruang moral dan simbol adat Minangkabau. Walaupun bentuk-bentuk rumah di Sumatera Barat selalu berubah-ubah, rumah gadang tradisional itu terkonseptualisasi dan terkristal terutama selama periode sistem tanam paksa kopi (1847-1908) (Hadler, 2008). Rumah gadang memiliki bentuk yang unik. Atapnya berbentuk meruncing menyerupai bentuk tanduk kerbau. Bentuk tanduk kerbau ini sering dihubungkan dengan cerita rakyat kemenangan Minangkabau saat invasi kerajaan Jawa ke Sumatera (Franzia, 2017; Kato, 1978).

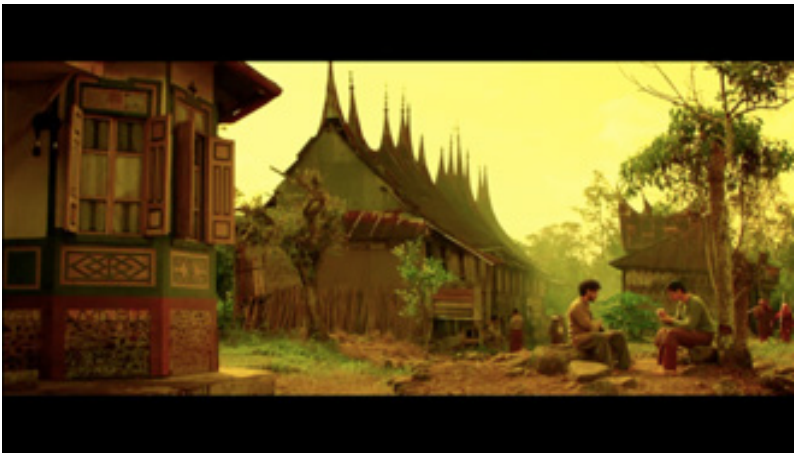

Sumber: tangkapan layar film Tenggelamnya Kapal van Der Wijck (2013)

Gambar 3 Zainuddin, Muluk, dan rumah gadang dalam Tenggelamnya Kapal van Der Wijck

Dalam film, rumah gadang muncul sebagai latar tempat, yaitu rumah tinggal tokoh, dan bagian desain latar tempat. Rumah gadang yang ditampilkan dalam film secara tidak langsung menunjukkan status sosial pemiliknya, yaitu suku atau kaum bukan pribadi. Bagi masyarakat Minangkabau, rumah gadang bukan semata sebagai tempat kediaman keluarga. Rumah gadang merupakan perlambang kehadiran satu kaum dalam satu nagari, serta sebagai pusat kehidupan dan kerukunan seperti tempat bermufakat keluarga kaum dan melaksanakan upacara (Bahauddin dkk., 2012; Navis, 1984; Prasetya \& Adi, 2011).

Tampilan rumah gadang dalam Harimau Tjampa (Gambar 1), Di Bawah Lindungan Ka'bah (Gambar 2), dan Tenggelamnya Kapal van der Wijck (Gambar 3) secara tidak langsung menunjukkan ragam bentuk rumah gadang di Minangkabau. Rumah gadang yang ditampilkan dalam ketiga film ini adalah rumah 
gadang Luhak Tanah Datar. Rumah gadang luhak ini dikenal dengan nama gajah maharam karena volume yang besar (Nakamura, 2001) dan memiliki ciri gonjong berjumlah enam atau lebih (Navis, 1984). Di samping itu, rumah gadang memiliki anjuang 'anjung'. Anjuang merupakan ruangan kecil di bagian kanan dan kiri rumah gadang dengan lantai lebih tinggi. Anjuang yang berada pada kedua bagian samping rumah gadang ini adalah ciri rumah gadang kelarasan Koto Piliang (Navis, 1984) dan dikenal dengan garudo tabang 'garuda terbang' (Ismael, 2007). Nakamura (2001) menyebut anjuang ini sebagai bagian pinggul atap rumah yang runcing.

Sementara itu, bentuk rumah gadang Luhak Agam dinamakan surambi papek 'serambi pepat' yang bentuknya seolah dipepat kedua ujungnya. Rumah gadang Luhak Lima puluh Koto dinamakan rajo babandiang 'raja berbanding' yang bentuknya serupa dengan rumah gadang Luhak Tanah Datar tetapi tidak beranjung (Navis, 1984). Nakamura (2001) menambahkan terdapat sebelas variasi bentuk arsitektur rumah gadang dari ketiga luhak Minangkabau dari enam bentuk dasarnya yaitu pariangan, balimbiang, balai cancang, payobasung, kudo batagak, dan koto gadang.

Terdapat bermacam-macam keterangan mengenai bentuk dasar atau rumah adat ini. Ada pendapat mengemukakan bentuk dasar ini diambil dari bentuk perahu sebagai kiasan mengarungi lautan kehidupan. Badan disebut mirip dengan bentuk perahu, sedangkan gonjong adalah tajuk pada haluan dan buritan perahu. Tajuk yang ditengah adalah kajang 'anjungan' perahu. Pendapat ini dikuatkan dengan julukan yang diberikan kepada tukang rumah adat yang disebut nankodoh rajo 'nahkoda raja'. Pendapat lain mengemukakan bahwa motif dasar atap rumah gadang berhubungan dengan sejarah Minangkabau. Dengan adanya kata kabau 'kerbau', maka gonjong rumah gadang disebut diambil dari bentuk dasar tanduk kerbau (Syafwandi, 1993).

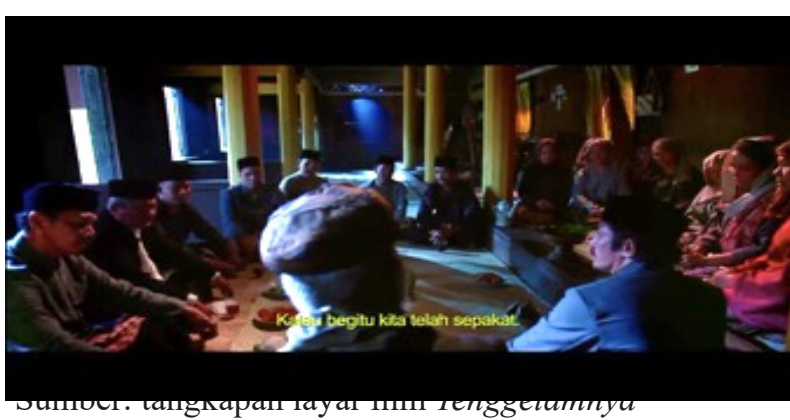

Kapal van Der Wijck (2013)

\section{Gambar 4 Perundingan pernikahan Hayati dalam Tenggelamnya Kapal van Der Wijck}

Rumah gadang juga muncul dalam space sebuah adegan. Di samping pendukung latar tempat, rumah gadang dalam space ini memperkuat penokohan dan pesan cerita. Hal ini juga didukung oleh posisi (blocking) aktor serta teknik pencahayaan yang turut mendukung suasana (Gambar 3). Tokoh Zainuddin dalam Tenggelamnya Kapal van der 
Wijck dianggap bukan orang Minangkabau oleh penduduk Batipuh karena ayahnya menikah dengan wanita Makasar. Namun demikian, Zainuddin tetap berusaha untuk dapat diterima menjadi bagian Minangkabau. Kesendirian dan perjuangan Zainuddin dalam tekanan kebesaran Minangkabau direpresentasikan melalui adegan pada Gambar 3. Komposisi blocking dengan tangkapan kamera menunjukkan usaha Zainuddin meraih Minangkabau dalam hidupnya. Hanya Muluk yang pada saat itu menemani dan menyemangati agar tetap hidup dan berusaha hingga berhasil.

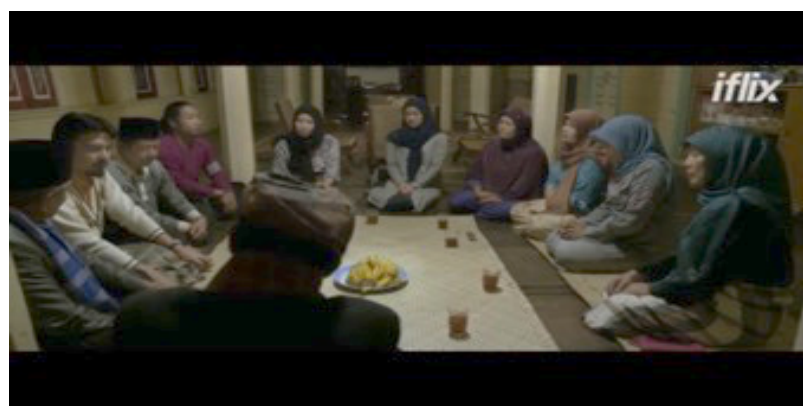

Sumber: tangkapan layar film Liam dan Laila (2018)

\section{Gambar 5 Perundingan pernikahan Laila dalam Liam dan Laila}

Dalam film Tenggelamnya Kapal van der Wijck dan Liam dan Laila, terdapat adegan tangkapan kamera yang serupa (Gambar 4 \& 5). Kedua adegan tersebut adalah peristiwa perundingan untuk perhelatan pernikahan yang dilaksanakan di dalam rumah gadang. Di samping menunjukkan peran dan kedudukan mamak sebagai penghulu kaum, Gambar 4 dan 5 juga menujukkan fungsi rumah gadang sebagai tempat permufakatan kaum (Navis, 1984). Posisi mamak (mengenakan saluak membelakangi kamera) menunjukkan peran dan kedudukannya sebagai pusat perundingan. Adegan ini juga memperlihatkan peran mamak dalam kaumnya sebagai tempat bertanya dan berunding untuk memecahkan masalah.

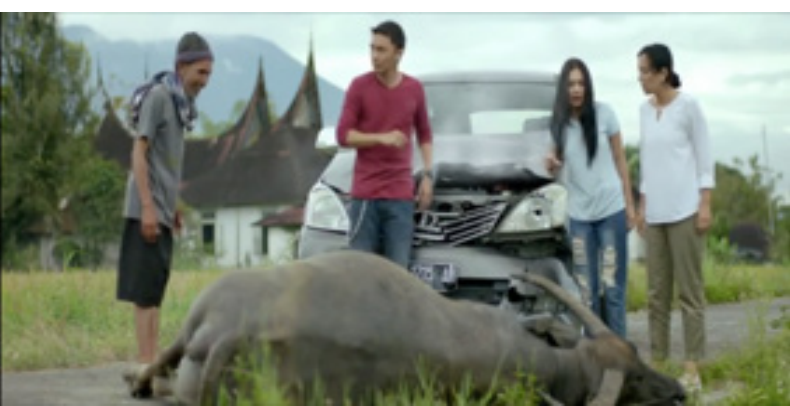

Sumber: tangkapan layar film Me vs Mami (2016)

\section{Gambar 6 Atap bagonjong dalam space dalam Me vs Mami}

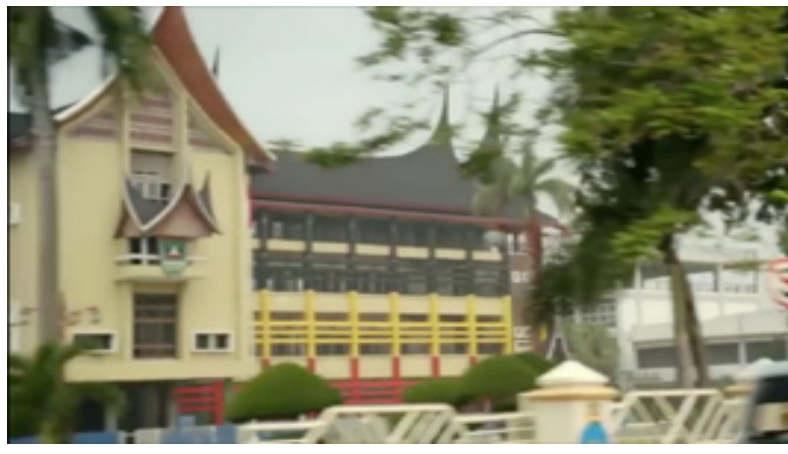

Sumber: tangkapan layar film Me vs Mami (2016)

Gambar 7 Atap bagonjong dalam latar

Bentuk atap rumah gadang (gonjong) kini bisa ditemui sebagai bentuk lambang visual sosial Minangkabau yang cenderung stereotip, misalnya lambang, logo, atau ikon yang berbentung gonjong (Couto, 2008). Bentuk atap rumah tinggal, kantor, maupun gedung fasilitas umum juga dibuat sebagai gonjong rumah gadang (Azmi \& Pane, 2018; Ralie dkk., 2019). 


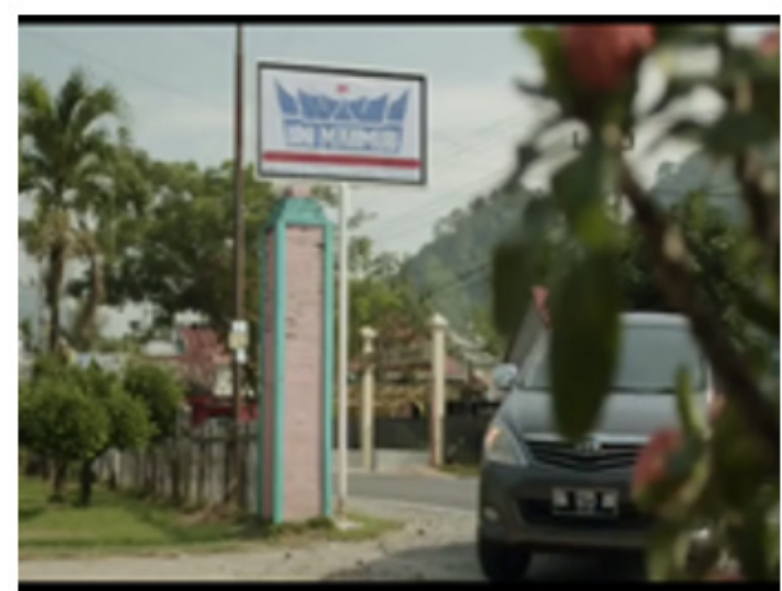

Sumber: tangkapan layar film Me vs Mami (2016)

\section{Gambar 8 Ikon atap gonjong}

Perkembangan teknik arsitektur rumah tinggal pada akhirnya juga berpengaruh pada kebertahanan rumah gadang sebagai bangunan tradisional Minangkabau (Damayanti, 2018). Munculnya perubahan ini adalah bagian dari perkembanganarsitektursebagai sebuah perilaku sosial. Kesetiaan masyarakat Minangkabau pada tradisi dan budayanya melahirkan kreativitas untuk merepresentasikannya. Ciri khas atap gonjong inilah yang kemudian diadaptasi menjadi bentuk-bentuk visual yang diidentikkan sebagai Minangkabau (Soenarto \& Sudyarto, 1983).

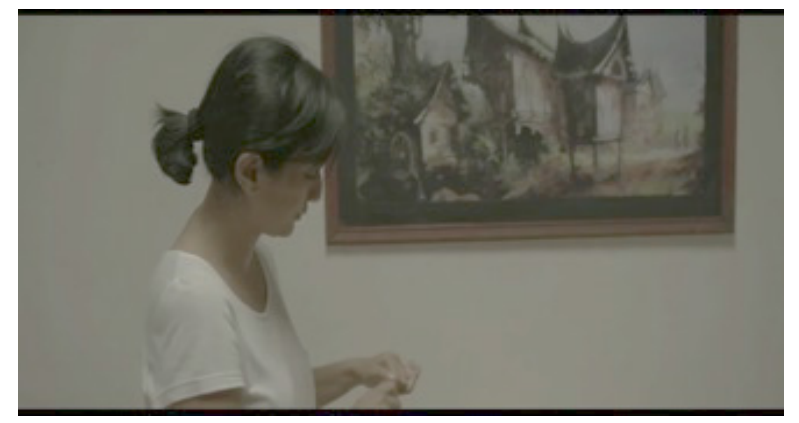

Sumber: tangkapan layar film Me vs Mami (2016)

Gambar 9 Lukisan rangkiang sebagai properti latar

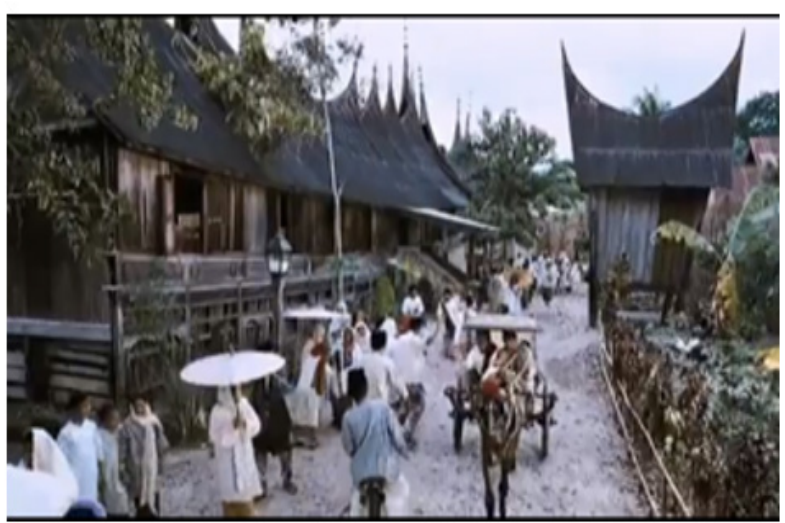

Sumber: tangkapan layar film Di Bawah Lindungan Ka'bah (2011)

\section{Gambar 10 Rumah gadang dan rangkiang}

Setiap rumah gadang mempunyai rangkiang yang ditegakkan di halaman depan. Rangkiang ialah bangunan tempat menyimpan padi milik kaum. Ada empat macam jenisnya dengan fungsi dan bentuk yang berbeda. Jumlah rangkiang yang terdapat di halaman memberikan tanda keadaan penghidupan kaum. Bentuk rangkiang sesuai dengan gaya bangunan rumah gadang. Atapnya bergonjong dan dibuat dari ijuk. Tiang penyangganya sama tinggi dengan tiang rumah gadang. Pintunya kecil dan terletak pada bagian atas dari salah satu dinding singkok (singkap) yaitu bagian segi tiga lotengnya. Tangga bambu untuk menaiki rangkiang dapat dipindahpindahkan untuk keperluan lain dan bila tidak digunakan disimpan di bawah kolong rumah gadang (Navis, 1984; Rahman dkk., 2019).

Rangkiang diyakini berasal dari kata Ruang Hiang Dewi Sri, dewi padi (Navis, 1984), yang merupakan lumbung tempat penyimpanan hasil pertanian terutama padi (Marthala, 2013; 
Nakamura, 2001; Navis, 1984). Rangkiang dibuat berjajar di halaman rumah gadang. Jumlah rangkiang disesuaikan dengan hasil pertanian dan kekayaan yang dimiliki kaum. Rangkiang adalah lambang kemakmuran dan pengaturan harta benda. Semakin banyak hasil panen, semakin bertambah jumlah rangkiang. Soenarto \& Sudyarto (1983) menyebut bahwa lumbung padi ini memegang perang simbolik sebagai "pameran” kemakmuran rumah gadang yang memilikinya. Bentuk atap rangkiang yang sama dengan rumah gadang yaitu gonjong pada akhirnya juga membawa rangkiang sebagai ikon bangunan Minangkabau (Ralie dkk., 2019).

Bentuk atap gonjong tunggal (terpotong) pada bagian pintu masuk rumah makan yang banyak ditemui kini diyakini berkaitan dengan atap rangkiang yang melambangkan fungsi menyediakan makanan bagi masyarakat(Franzia dkk., 2015). Atap gonjong adalah elemen kuat yang selalu menghiasi restoran-restoran Padang sebagai penanda kehadiran para perantau dari Minangkabau. Bagi pengunjung elemen ini sangat mudah dikenali sebagai penciri rumah makan Padang (Khamdevi, 2017). Uraian di atas menunjukkan bahwa bangunan, gedung, rumah tinggal, dan propertinya adalah bagian dari lanskap yang juga merupakan wujud teks yang dominan membangun narasi cerita (Lukinbeal, 2005).

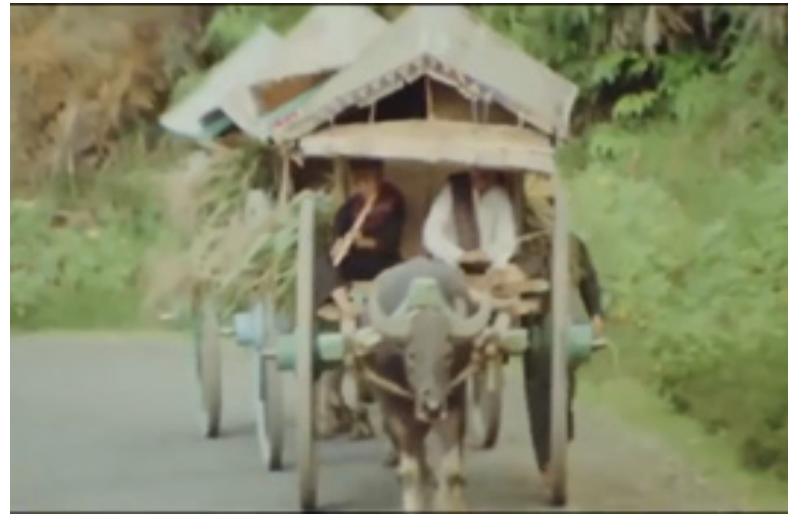

Sumber: tangkapan layar film Para Perintis Kemerdekaan (1977)

Gambar 12 Pedati sebagai properti dalam latar 


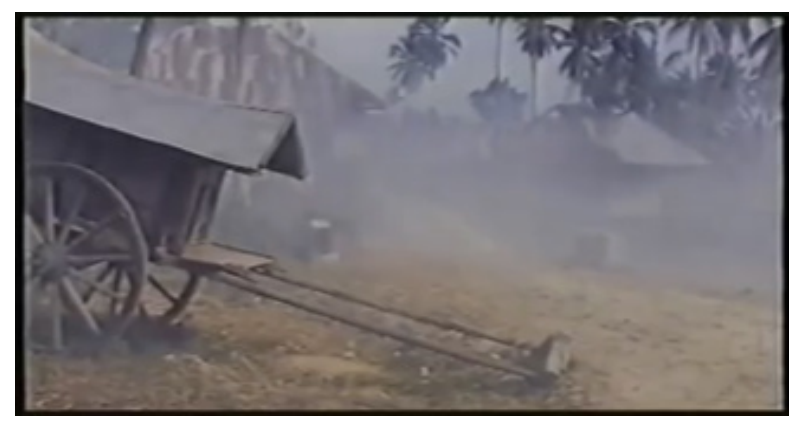

Sumber: tangkapan layar film Titian Serambut Dibelah Tujuh (1986)

\section{Gambar 13 Pedati sebagai properti dalam latar}

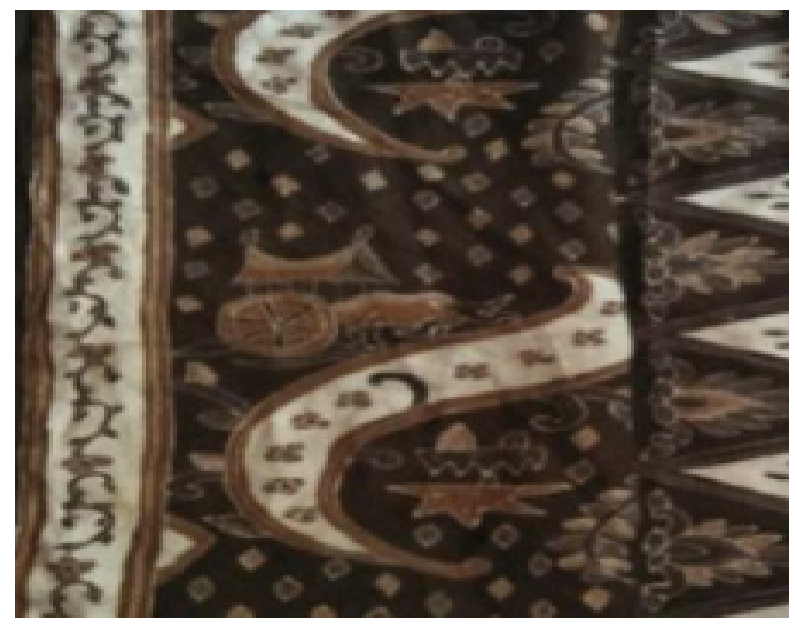

Sumber: (Oktora \& Adriani, 2019)

\section{Gambar 14 Motif batik kabau padati}

Di samping turut menjelaskan latar tempat, ditampilkannya pedati dalam Harimau Tjampa, Para Perintis Kemerdekaan dan Titian Serambut Dibelah Tujuh juga mendukung latar waktu. Dalam hal ini, pedati turut menegaskan moda transportasi yang ada sesuai latar waktu cerita.

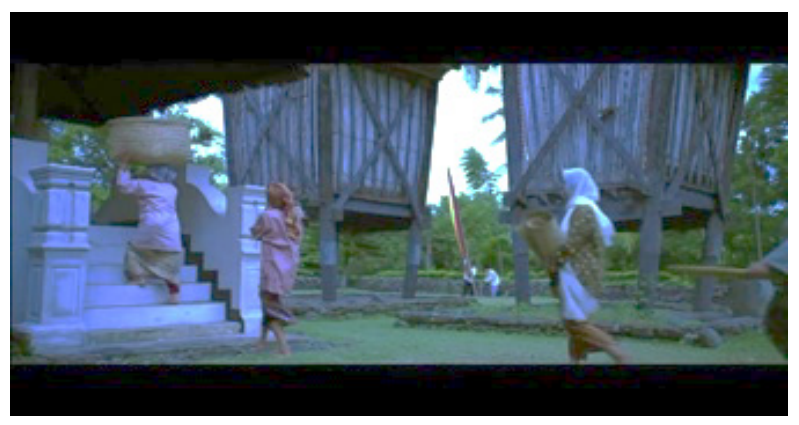

Sumber: tangkapan layar film Di Bawah Lindungan Ka'bah (2011)

\section{Gambar 15 Rangkiang dan marawa sebagai properti latar}

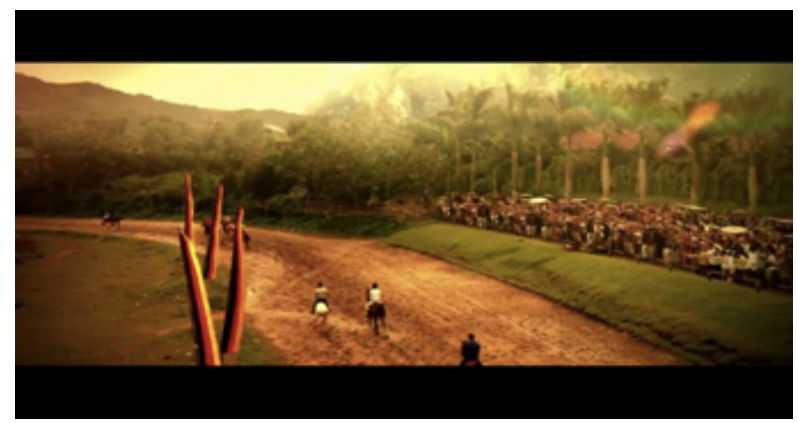

Sumber: tangkapan layar film Tenggelamnya Kapal van Der Wijck (2013)

\section{Gambar 16 Marawa sebagai properti dalam latar}

Unsur keminangkabauan yang ditampilkan dalam space dan latar lainnya adalah marawa. Marawa dapat disamakan dengan bendera atau umbul-umbul yang menandakan adanya perhelatan di wilayah Minangkabau (Franzia dkk., 2015; Rahman dkk., 2019). Warna hitam, kuning (emas), dan merah adalah ciri khas mawara yang melambangkan harmonisasi kehidupan masyarakat Minangkabau. 


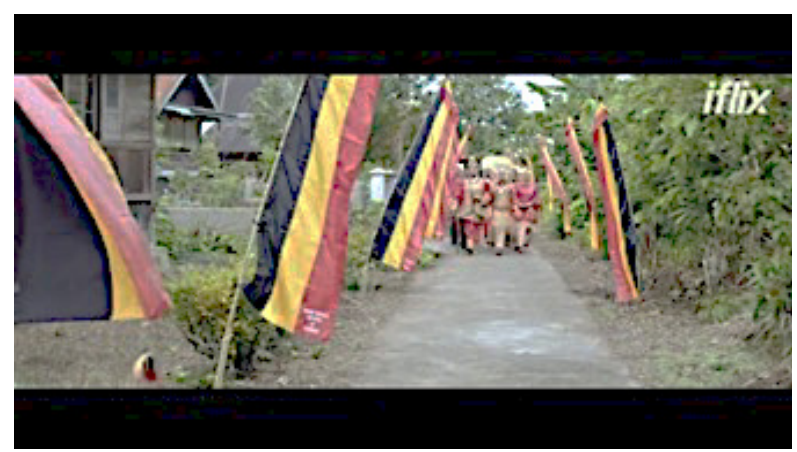

Sumber: tangkapan layar film Liam dan Laila (2018)

Gambar 17 Marawa sebagai properti dalam latar

Dapat dikatakan bahwa marawa merupakan lambang Minangkabau. Marawa adalah umbul-umbul adat Minangkabau yang juga melambangkan wilayah budaya Minangkabau (Luhak Nan Tigo) (Franzia, 2017). Hitam melambangkan Luhak Limo Puluah Koto, kuning melambangkan Luhak Tanah Datar, dan merah melambangkan Luhak Agam. Di samping itu, ketiga warna tersebut juga mengandung makna adat Minangkabau yaitu hitam bermakna kepemimpinan dan tahan tempa, kuning bermakna kebesaran, keagungan, dan kehormatan, serta merah bermakna keberanian dan tahan uji (Franzia, 2016).

Salah satu fungsi marawa adalah sebagai penanda perhelatan besar terdapat dalam pantun ungkapan berikut. Panggilan sisiak pelapahan, dipanggia sampai tabao, pakai tombak pakai gandaio, sarato padang jinawi baapikan, dikambang payuang ubua-ubua, tapancang marawa di halaman. langkok jo gong jo talempong, dilapeh jo latuih badia, bapakaian adaik salangkoknyo 'panggilan sisik pelepahan, dipanggil sampai datang, dengan tombak dan gendola, serta pedang jenawi berapitan, dikembang payung uburubur, dipanjang merawa di halaman, lengkap dengan gong dan telempong. dilepas dengan letusan bedil berpakaian kebesaran lengkap semuanya'. Maksudnya semua orang diundang dengan cara sesuai dengan kedudukan mereka masing-masing sehingga tidak seorang pun yang terlupakan (Navis, 1984).

Kostum, pakaian, dan aksesorisnya juga merupakan elemen visual yang penting dalam film. Melalui kostum, film dapat menunjukkan latar waktu dan latar sosial cerita. Dalam hal ini, bagian kostum yang menunjukkan keminangkabauan adalah penutup kepala yang dikenal sebagai saluak, suntiang, dan tangkuluak.

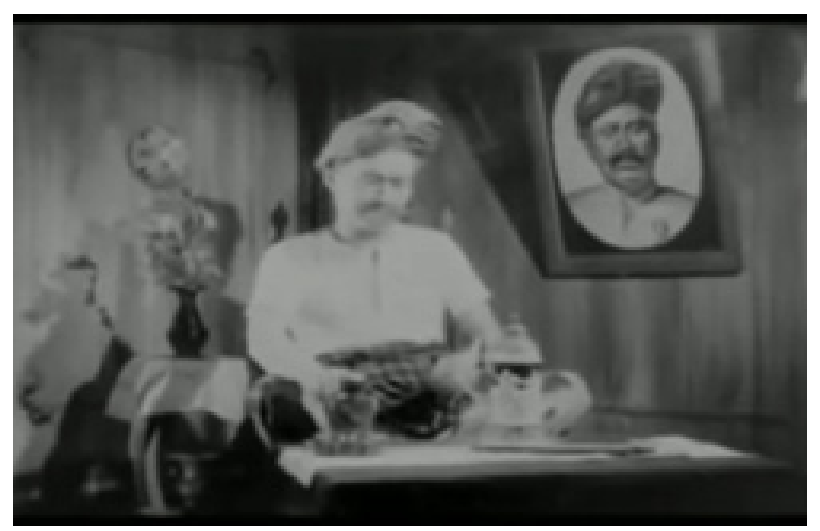

Sumber: tangkapan layar film Harimau Tjampa (1953)

Gambar 18 Saluak Datuk Langit 


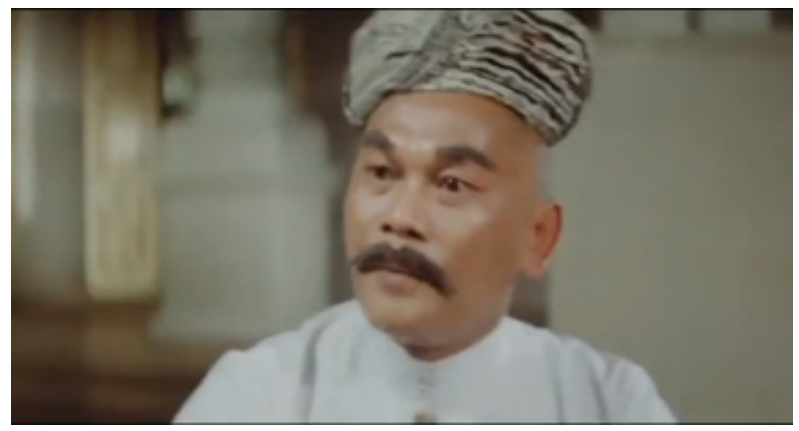

Sumber: tangkapan layar film Para Perintis Kemerdekaan (1977)

\section{Gambar 19 Saluak Tuan Demang}

Saluak merupakan penutup kepala yang dikenal dikenakan oleh penghulu Minangkabau. Saluak, pada bagian depan ditata berkerut-kerut yang berbentuk jenjang dan bagian atasnya datar, sedangkan bagian belakang berbentuk bundar dan melingkar di bagian belakang (Anwar dkk., 2019).

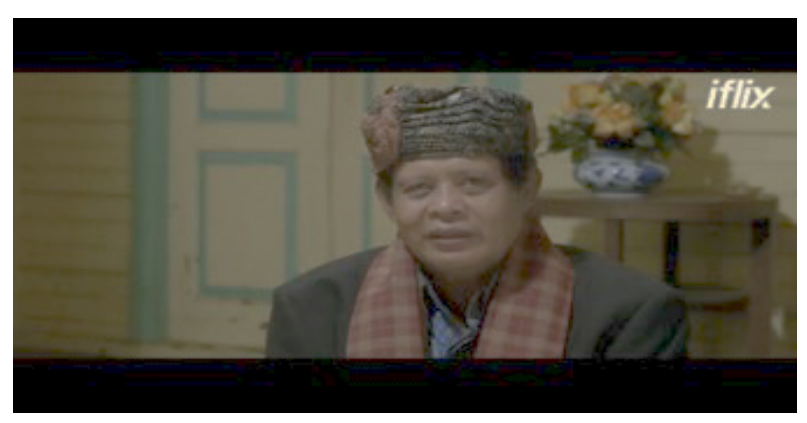

Sumber: tangkapan layar film Liam dan Laila (2018)

\section{Gambar 20 Saluak mamak Laila}

Selain dikenakan oleh penghulu, saluak juga dikenakan oleh marapulai (mempelai laki-laki) saat upacara pernikahan. Mempelai laki-laki di beberapa daeraah di Minangkabau mengenakan saluak yang terbuat dari balapak, yaitu kain kain tenun dari Pandai Sikek
Padangpanjang (Maresa, 2009). Di beberapa daerah lain, saluak terbuat dari kain batik katun dengan hiasan motif flora, fauna, atau geometris (Yunus dkk., 2014).

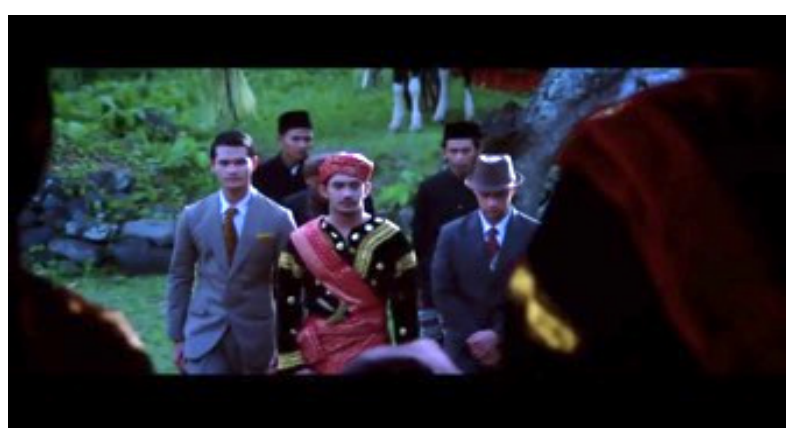

Sumber: tangkapan layar film Tenggelamnya Kapal van Der Wijck (2013)

\section{Gambar 21 Pakaian adat pernikahan laki-laki}

Di samping itu, busana pengantin wanita dalam Liam dan Laila yang juga menunjukkan muatan keminangkabauan adalah asuntiang. Suntiang adalah hiasan kepala yang dikenakan anak daro (mempelai wanita) (Yunus dkk., 2014). Suntiang berarti pengantin wanita yang dilambangkan dengan bunga yang sedang mekar. Suntiang ini memiliki fungsi untuk memukau atau menarik perhatian para tamu yang hadir dalam upacara pernikahan, agar mendapat pengakuan sebagai suami istri. Bahan yang dipergunakan untuk suntiang adalah emas, perak atau imitasi yang berwarna kuning emas (Maresa, 2009) (Gambar 15).

Suntiang ini berbahan emas dan dikenakan untuk membangun kesan anggun dan megahnya 
mempelai perempuan (Azami dkk., 1997). Dalam film Liam dan Laila (Gambar 22), tampak pula pengiring pengantin mengenakan hiasan kepala suntiang dan tingkuluak. Tingkuluak adalah kain penutup kepala wanita yang berpakaian adat (Hurahmi, 2015). Melalui bentuknya, tingkuluak yang dikenakan oleh pengiring dalam Liam dan Laila adalah tingkuluak tanduak. Tingkuluak tanduak memiliki ciri ujung meruncing menyerupai tanduk kerbau. Suntiang yang dikenakan oleh pengiring pengantin disebut suntiang ketek (kecil) (Mustika \& Budiwirman, 2019). Warna merah dan kuning keemasan dalam adegan pernikahan tokoh juga mendukung pembangunan latar tempat film Liam dan Laila, yaitu Bukittinggi. Merah melambangkan keberanian dan kuning keemasan memberikan kesan mewah kepada pemakainya (Yunus dkk., 2014).

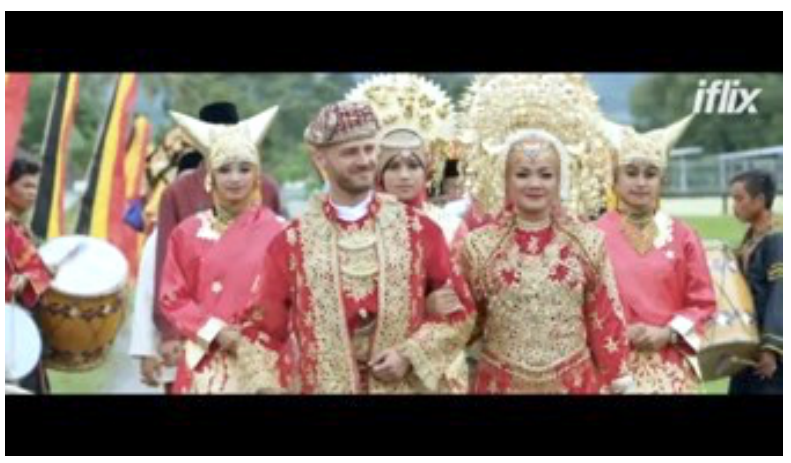

Sumber: tangkapan layar film Liam dan Laila (2018)

Gambar 22 Pakaian adat pernikahan Liam dan Laila

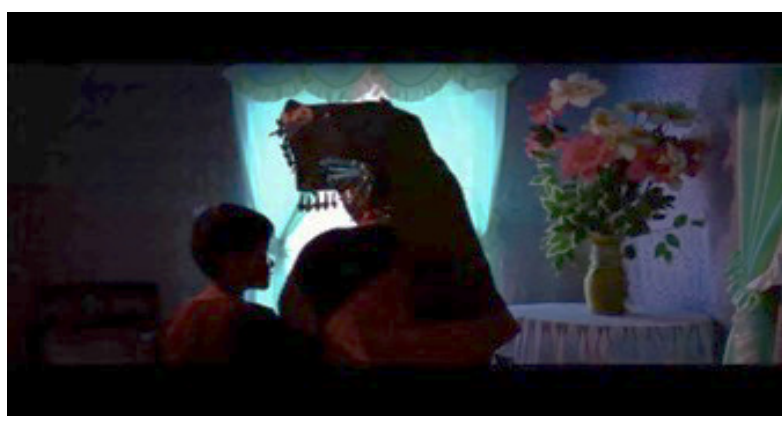

Sumber: tangkapan layar film Tenggelamnya Kapal van Der Wijck (2013)

Gambar 23 Hayati menjelang pernikahan

Dalam Tenggelamnya Kapal van der Wijck, pada upacara pernikahannya, Hayati tampak mengenakan tangkuluak. Tangkuluak adalah salah satu pakaian adat bundo kanduang yang lazim dikenakan pada upacara perhelatan. Menurut Ernanda, dkk. (2018), tangkuluak ini melambangkan kebangsawanan dan tidak bolehnya bundo kanduang menjunjung beban yang berat serta menggambarkan bahwa demokrasi lebih diutamakan di kawasan kenagarian tetapi berada pada batas-batas tertentu.

Berbeda dengan suntiang yang dikenakan oleh mempelai perempuan, tingkuluak oleh masyarakat Minangkabau dikenal dikenakan oleh perempuan dalam upacara adat. Terdapat beragam jenis dan fungsi tingkuluak yang dikenal masyarakat Minangkabau. Salah satunya dikenal sebagai tingkuluak yang dikenakan hanya oleh bundo kanduang, yaitu tingkuluak balapak (Ernanda dkk., 2018). 
Jenis ini tampak pada citraan visual tingkuluak yang dikenakan Hayati saat pernikahaannya (Gambar 23). Tingkuluak adalah pakaian adat bundo kanduang sebagai pemimpin satu kaum yang lazim dikenakan pada upacara perhelatan (Ernanda dkk., 2018). Tengkuluk melambangkan rumah gadang karena anggota masyarakat beranggapan bahwa rumah adat itu adalah milik kaum wanita/ibu. Dataran yang terdapat di atas tengkuluk melambangkan bahwa dalam memutuskan sesuatu harus melalui musyawarah mufakat dengan hasil yang adil (datar) (Ibrahim dkk., 1985).

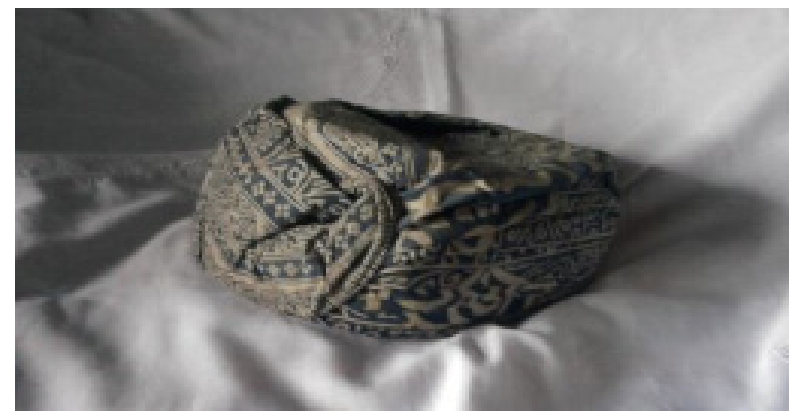

Sumber: (Anwar dkk., 2019)

\section{Gambar 24 Saluak}

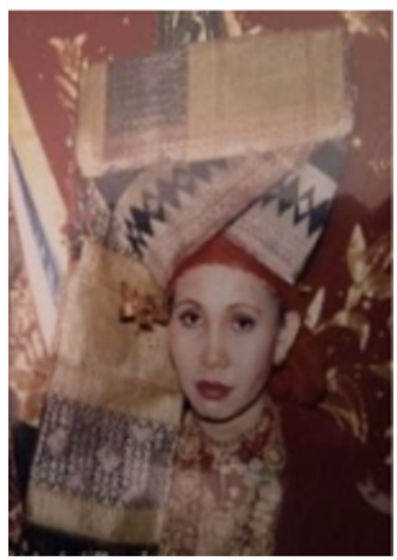

Sumber: Ernanda dkk., 2018

Gambar 25 Tangkuluak
Kostum yang dikenakan dalam film-film bermuatan Minangkabau ternyata berhubungan erat dengan bangunan struktur naratif lainnya. Saluak yang dikenakan tokoh, tidak hanya menunjukkan muatan keminangkabauan, tetapi juga mendukung tokoh dan penokohan. Dalam Harimau Tjampa dan Para perintis Kemerdekaan, saluak yang biasanya dikenakan saat perhelatan, oleh tokoh dikenakan dalam keseharian. Tampilan ini dimunculkan tampaknya untuk memperkuat peran status sosial dan keangkuhan tokoh Datuk Langit (Gambar 18) dan Angku Demang (Gambar 19).

Warna merah dan kuning keemasan dalam adegan pernikahan tokoh juga mendukung pembangunan latar tempat film Liam dan Laila, yaitu Bukittinggi. Merah melambangkan keberanian dan kuning keemasan memberikan kesan mewah kepada pemakainya (Yunus dkk., 2014). Pakaian tradisional acara pernikahan yang berbeda ditunjukkan dalam Tenggelamnya Kapal van der Wijck. Pemilihan dan penentuan kostum juga memperhitungkan latar cerita yaitu di Batipuh Payakumbuh dan penokohan. Tokoh Azis adalah anak Sutan Mantari, orang terpandang di nagari Batipuh. Oleh karenanya, baju yang dikenakan saat pernikahannya dengan Hayati tidak jauh berbeda dengan pakaian seorang penghulu yang menunjukkan bahwa tokoh adalah orang terpandang (Gambar 21). 


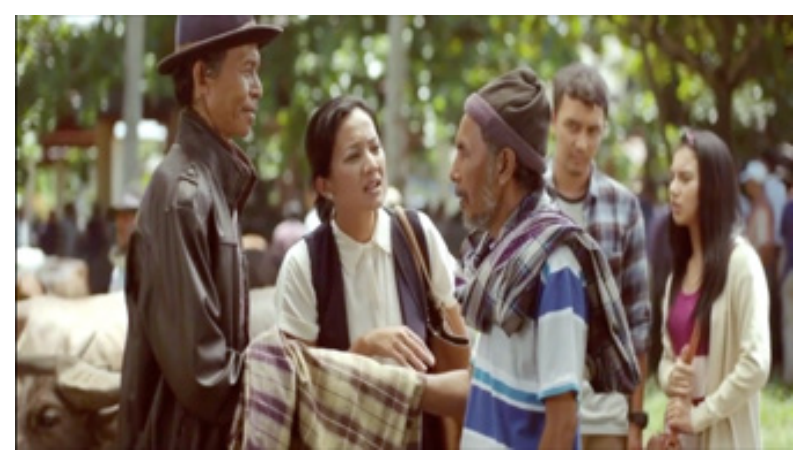

Sumber: tangkapan layar film Me vs Mami (2016)

\section{Gambar 26 Marosok}

Dalam Me vs Mami, terdapat satu adegan yang menunjukkan penguatan terhadap latar cerita. Peristiwa itu terjadi di pasar hewan saat transaksi jual beli kerbau oleh tokoh Pak Nurdin dengan seorang penjual ternak (Gambar 26). Proses tawar menawar dilakukan dengan isyarat jari tangan yang ditutup dengan kain sarung. Adegan peristiwa ini secara langsung menunjukkan latar cerita yaitu di Payakumbuh, Sumatera Barat. Adapun proses tawar menawar ini disebut marosok (Fadhilah \& Dewi, 2017; Umassari, 2018). Akting Maudy (Cut Mini) menunjukkan ketidaktahuannya tentang tradisi itu.

Marosok dalam tradisi ini dapat diartikan sebagai meraba tanpa melihat. Marosok adalah tawar menawar antara penjual dan pembeli dilakukan tanpa suara menggunakan bahasa isyarat. Tradisi marosok adalah suatu bentuk perilaku budaya masyarakat Minangkabau yang dilakukan di beberapa daerah di Sumatera Barat. Karena kekhasannya, marosok ditetapkan sebagai Warisan Budaya Tak Benda (WBTB) dari Sumatera Barat pada tahun 2020 dalam domain pengetahuan dan kebiasaan perilaku mengenai alam dan semesta.

Proses tawar menawar morosok ini dilakukan dengan isyarat jari tangan dengan bersalaman dan ditutup dengan kain sarung. Hal ini dilakukan agar tidak terjadi persaingan harga antar penjual (Fadhilah \& Dewi, 2017). Dengan demikian dapat dicapai kesepakatan harga yang sesuai (Umassari, 2018) dan tidak terjadi penjual lain menyela transaksi untuk menyaingi harga (Putri, 2015).

Aspek mise-en-scene lainnya yaitu teknik pencahayaan dan posisi aktor (blocking) yang secara tidak langsung juga menguatkan visualisasi unsur-unsur keminangkabauan. Pencahayaan dalam teknik mise-en-scene tidak hanya berfungsi menerangi latar maupun tokoh. Teknik pencahayaan dimanfaatkan untuk mendukung pembentukan karakter tokoh dan latar suasana cerita (Lathrop \& Sutton, 2013).

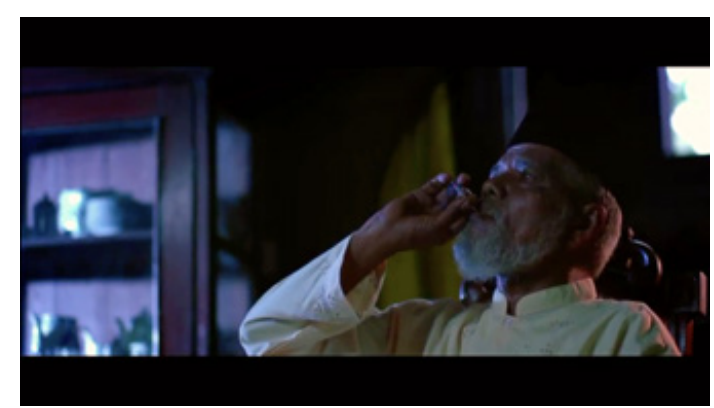

Sumber: tangkapan layar film Tenggelamnya Kapal van Der Wijck (2013)

Gambar 27 Datuak Marajo mamak Hayati 
Pada umumnya, teknik pencahayaan yang digunakan dalam film adalah pencahayaan utama (key/main light), pencahayaan pengisi (fill light), dan pencahayaan belakang (backlight) (Lewis, 2014). Dalam praktiknya, variasi teknik pencahayaan adalah salah satu keahlian kreator film dalam menyajikan adegan kamera. Gambar 16 menunjukkan variasi teknik pencahayaan antara low-key light dengan under backlight yang menghasilkan penguatan karakter tokoh. Pencahayaan utama yang rendah menghasilkan terang yang kontras dengan sekelilingnya. Adanya cahaya belakang dari posisi bawah didukung blocking dan akting aktor, karakter tokoh menjadi semakin kuat.

Di Minangkabau, mamak merupakan pemimpin. Oleh karena itu, pengertian mamak pada setiap laki-laki yang lebih tua juga berarti pernyataan bahwa yang muda memandang yang lebih tua menjadi pimpinannya (Navis, 1984). Kepemimpinan dan ketegasan seorang mamak dalam suatu kaum di Minangkabau pada Gambar 27 tampak diperkuat dengan teknik pencahayaan tersebut.

Secara umum dapat dikatakan film Tenggelamnya Kapal van der Wijck memanfaatkan teknik low light untuk pencahayaan. Di samping pertimbangan artistik, teknik low light digunakan untuk memperkuat kesan terhadap tampilan kamera. Teknik pencahayaan low-key light dengan high backlight dapat dilihat dalam Gambar 23. Cahaya utama yang rendah dengan cahaya belakang yang tinggi memperjelas sosok Hayati dan adiknya dalam tangkapan kamera. Di samping membangun suasana adegan, teknik pencahayaan ini juga memperjelas garis dan lekuk kostum hiasan kepala yang digunakan tokoh, yaitu tingkuluak. Tingkuluak merupakan perlengkapan pakaian adat bundo kanduang di Minangkabau (Ernanda dkk., 2018). Di beberapa daerah di Sumatera Barat, di samping suntiang sebagai hiasan kepala, mempelai wanita diketahui mengenakan tingkuluak ini.

Teknik pencahayaan menggunakan natural light menguatkan adegan marosok yang terjadi secara alami (Gambar 26). Menurut Lewis (Lewis, 2014), teknik pencahayaan natural banyak dan baik digunakan untuk pencahayaan adegan baik di luar maupun di dalam ruangan untuk meraih efek alami sebuah adegan. Pencahayaan dalam teknik ini biasa menggunakan cahaya matahari atau bulan secara alami.

Blocking dan akting aktor dalam film sangat penting dalam pembentukan karakter tokoh cerita. Aktor dan sutradara menjadi faktor penting dalam aspek ini. Dalam hal ini, akting dan blocking tidak hanya merujuk pada posisi aktor dalam tangkapan kamera, tetapi juga meliputi ekspresi dan gestur dalam membawakan peran dalam film. Di samping 
itu, aspek mise-en-scene ini juga pada akhirnya turut membangun pesan cerita melalui kamera.

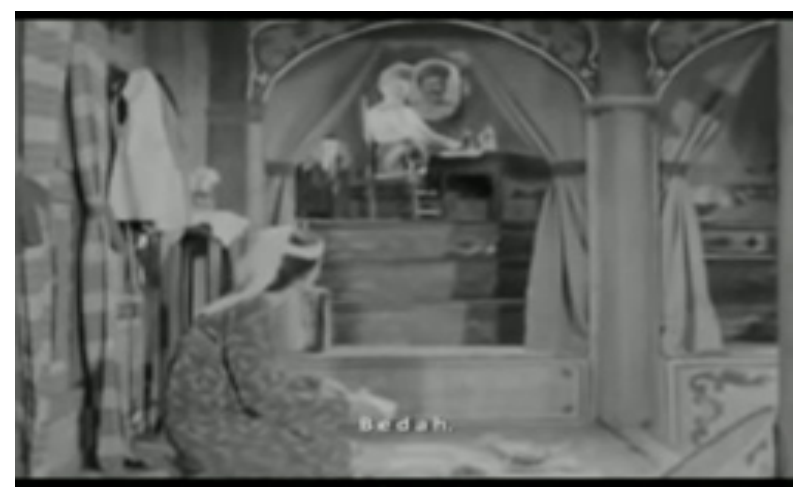

Sumber: tangkapan layar film Harimau Tjampa (1953)

\section{Gambar 28 Datuk Langit dan istrinya}

Sebagai tokoh antagonis dalam Harimau Tjampa, Datuk Langit ditampilkan sebagai tokoh kaya dan angkuh. Baik gestur maupun posisinya dalam kamera (Gambar 28) sengaja ditampilkan untuk mendukung karakterisasi tokoh ini. Di samping itu, penyajian tokoh Datuk Langit (Gambar 28) dapat dikatakan sebagai representasi mamak yang tidak ideal menurut adat Minangkabau dengan meninggikan posisi dan derajatnya dari istrinya (Navis, 1984).

Tokoh Zainuddin dalam Tenggelamnya Kapal van der Wijck dianggap bukan orang Minangkabau oleh penduduk Batipuh karena ayahnya menikah dengan wanita Makasar. Namun demikian, Zainuddin tetap berusaha untuk dapat diterima menjadi bagian Minangkabau. Kesendirian dan perjuangan Zainuddin dalam tekanan kebesaran Minangkabau direpresentasikan melalui adegan pada Gambar 3. Komposisi blocking dengan tangkapan kamera menunjukkan usaha Zainuddin meraih Minangkabau dalam hidupnya. Hanya Muluk yang pada saat itu menemani dan menyemangati agar tetap hidup dan berusaha hingga berhasil.

Melaluibeberapatemuandiatas, dapatdilihat bahwa tiap aspek mise-en-scene dalam sebuah film selalu berhubungan dengan aspek lainnya dalam membangun struktur naratif, khususnya menampilkan muatan keminangkabauan. Selain membangun suasana, pemilihan tempat sebagai latar dan blocking aktor menjadi faktor penting dalam memperkuat karakter tokoh (Gambar 28). Demikian pula perancangan kostum aktor yang juga turut membentuk karakter maupun watak tokoh. Di samping itu, kostum juga mendukung jalinan peristiwa dalam membentuk keutuhan tema (Gambar 21 dan 22). Di sisi lain, posisi (blocking) dan akting pemeran turut pula berperan menyampaikan muatan keminangkabauan. Kombinasi blocking dengan latar serta teknik pencahayaan (Gambar 3) membentuk suasana dan kekuatan karakter tokoh dalam tangkapan kamera. Adegan perundingan yang dilakukan di dalam rumah gadang (Gambar 4 dan 5) menjadi representasi demokrasi masyarakat Minangkabau.

Secara umum, tampilnya rumah gadang, rangkiang (lumbung), dan bentuk atap gonjong dalam film merupakan dukungan terhadap 
bangunan latar tempat dan sosial Minangkabau.

Secara visual, bentuk-bentuk ini muncul sekilas sebagai bagian dari ruang latar (space) sebuah adegan peristiwa. Dalam film Me vs Mami, munculnya rumah gadang dan rangkiang hanya sebagai pembangun latar cerita, terutama latar tempat. Disesuaikan dengan alur cerita, visualisasi atap gonjong dalam desain latar tempat yang dibangun tampak hanya sebagai pelengkap untuk memperkuat latar cerita di wilayah Minangkabau (Sumatera Barat). Hal ini ditunjukkan melalui tampilan atap gonjong sebagai bagian dari space latar tempat. Sepanjang cerita film ini, tidak ditampilkan fungsi rumah gadang maupun rangkiang dalam konteks sosial Minangkabau. Demikian pula munculnya rumah gadang dan rangkiang pada film Di Bawah Lindungan Ka'bah yang hanya sebatas upaya pembangunan latar cerita, baik tempat maupun sosial serta suasana. Munculnya arak-arakan pengantin dalam Para Perintis Kemerdekaan juga hanya sebatas pendukung bangunan latar cerita tanpa membawa etnisitas Minangkabau sebagai muatan utama adegan.
Perlu digarisbawahi bahwa film tidak hanya dilihat sebagai media massa belaka, tetapi juga dilihat sebagai institusi bisnis (Permana dkk., 2019). Tampilnya muatan Minangkabau dalam film, baik disadari maupun tidak, merupakan wujud representasi industri. Kekayaan Minangkabau dipandang oleh kekuatan industri sebagai komoditas yang menguntungkan. Perlu kearifan untuk menyikapi munculnya citraan visual sebagai wujud etnisitas, terutama Minangkabau.

\section{SIMPULAN}

Secara umum, munculnya Minangkabau dalam film masih didominasi dengan bentuk visual yang cenderung telah dikenal khalayak penonton. Bentuk visual rumah gadang, rangkiang, atap gonjong, saluak, suntiang, marawa, dan pedati masih menjadi pilihan utama representasi Minangkabau. Akan tetapi, kesadaran akan etnisitas tidak serta merta menjadi ukuran penghakiman terhadap muatan identitas etnik dalam film. Sebagai sebuah

Tabel 1 Hubungan Visualisasi Unsur Minangkabau dengan Struktur Penceritaan Film

\begin{tabular}{cllc}
\hline No & Citraan visual & \multicolumn{2}{c}{ Struktur penceritaan } \\
\hline 1 & Rumah gadang, rangkiang, atap gonjong & Latar tempat dan sosial & Tematik \\
2 & Pakaian/kostum & Penokohan, latar tempat dan sosial & Tematik \\
3 & Properti: marawa, pedati & Latar tempat dan sosial & - \\
4 & Marosok & Latar tempat dan sosial, alur & - \\
\hline
\end{tabular}

Sumber: Hasil penelitian, 2020 
representasi dan karya fiksi, film merupakan sebuah produk sekaligus proses sosial. Di satu sisi, film menggambarkan sebuah proses sosial dengan kemungkinan perubahan dan perbedaan. Di sisi lain, film merupakan produk proses sosial tersebut dalam bentuk karya seni.

Artikel ini merupakan kajian awal terhadap muatan keminangkabauan yang ditampilkan dalam film. Secara visual, bukan tidak mungkin unsur-unsur keminangkabauan tersebut juga membawa pesan untuk penonton. Munculnya kritik etnisitas terhadap film bermuatan Minangkabau justru akan menjadi pemicu kreativitas kreator film untuk berkarya.

Tidak bisa dipungkiri bahwa kekuatan lokalitas dalam film masih didominasi oleh visualisasi ikon dan kecenderungan stereotip. Pengetahuan kolektif penonton sebagai konsumen seolah menjadi pertimbangan pertama ditampilkannya unsur-unsur lokalitas.

Masih banyak muatan keminangkabauan yang bisa dijadikan sumber penciptaan film. Namun demikian, keragaman lokalitas Indonesia masih belum sepenuhnya diolah dan ditampilkan. Kekayaan muatan lokal inilah yang bisa menjadi alternatif sebuah penciptaan karya seni, terutama film. Teknologi dan kreativitas seniman perfilman menjadi modal perwujudannya. Hasil kajian ini diharapkan membuka peluang untuk kajian lanjutan terhadap muatan keminangkabauan dalam film dalam kerangka pemaknaan baik aspek visual maupun aspek naratifnya.

\section{DAFTAR PUSTAKA}

Anggraini, S. N. (2016). “Aku Yang Galau”: Refleksi Film Masa Kolonial Hingga Awal Kemerdekaan. REKAM: Jurnal Fotografi, Televisi, Dan Animasi, 11(2), 79. https:// doi.org/10.24821/rekam.v11i2.1295

Anwar, R., Sastra, A. I., \& Zebua, E. (2019). Pakaian Panghulu di Nagari Gunuang Kota Padangpanjang Provinsi Sumatera Barat. Gorga Jurnal Seni Rupa, 08(2), 332-336.

Arief, M. (2016). Analisis Konteks Islam dan Budaya Minangkabau dalam Skenario Film Titian Serambut Dibelah Tujuh. Menara Ilmu, X(2), 213-216. https://doi. org/10.33559/MI.V10I73.66

Azami, Nurdin, B., Abizar, Darwis, A., Bustami, Atarmizi, ... Naim, S. (1997). Adat dan Upacara Perkawinan Daerah Sumatera Barat. Jakarta: Departemen Pendidikan dan Kebudayaan.

Azmi, A., \& Pane, I. F. (2018). Penerapan Arsitektur Tradisional Minangkabau pada Bangunan Perkantoran Bukittinggi. Jurnal Arsitektur Dan Perkotaan "KORIDOR," 09(02).

Bahauddin, A., Hardono, S., Abdullah, A., \& Maliki, N. Z. (2012). The Minangkabau house: Architectural and cultural elements. WIT Transactions on Ecology and the Environment, 165, 15-25. https://doi. org/10.2495/ARC120021

Branigan, E., \& Buckland, W. (Eds.). (2014). The Routledge Encyclopedia of Film Theory. London - New York: Routledge.

Brown, B. (2012). Cinematography: Theory and Practice, Image Making for Cinematographers and Directors. 
Amsterdam $\bullet$ Boston $\bullet$ Heidelberg $\bullet$ London

- New York - Oxford Paris - San Diego

- San Francisco - Singapore - Sydney •

Tokyo: Elsevier - Focal Press.

Couto, N. (2008). Budaya Visual Seni Tradisi Minangkabau. Padang: Universitas Negeri Padang Press.

Damayanti, R. A. (2018). Kebertahanan Atap Gonjong Dan Perubahan Arsitektur Di Wilayah Sumatera Barat. Jurnal Dimensi Seni Rupa Dan Desain, 15(1), 31. https:// doi.org/10.25105/dim.v15i1.4195

Eneste, P. (1991). Novel dan Film. Flores: Nusa Indah.

Ernanda, E., Syafwandi, \& Jupriani. (2018). Studi Bentuk, Fungsi, dan Makna Tingkuluak Adat di Sungayang. Serupa Journal of Art Education, 6(2). Retrieved from http://ejournal.unp.ac.id/index.php/ serupa/article/view/9132

Everett, W. (Ed.). (2005). European Identity in Cinema. Bristol - Portland: Intelect Ltd.

Fadhilah, S., \& Dewi, E. A. S. (2017). Pola Komunikasi Tradisi Marosok antara Sesama Penjual dalam Budaya Dagang Minangkabau. Jurnal Kajian Komunikasi, 5(2), 222. https://doi.org/10.24198/jkk. v5i2.10464

Franzia, E. (2016). Identitas Virtual Masyarakat Etnis Minangkabau sebagai Wujud Eksistensi Budaya Nusantara. Proceeding Seminar Seni Budaya Antarbangsa: Koeksistensi Seni Budaya Nusantara Untuk Memperkokoh Identitas Kebangsaan, 397. Malang: Universitas Negeri Malang.

Franzia, E. (2017). Cultural Wisdom of Minangkabau Ethnic Community for Local - Global Virtual Identity. Mediterranean Journal of Social Sciences, 8(1), 325329. https://doi.org/10.5901/mjss.2017. v8n 1 p325
Franzia, E., Piliang, Y. A., \& Saidi, A. I. (2015a). Manifestation of Minangkabau Cultural Identity through Public Engagement in Virtual Community. Procedia - Social and Behavioral Sciences, 184, 56-62. https:// doi.org/10.1016/j.sbspro.2015.05.053

Franzia, E., Piliang, Y. A., \& Saidi, A. I. (2015b). Rumah Gadang as a Symbolic Representation of Minangkabau Ethnic Identity. International Journal of Social Science and Humanity, 5(1), 44-49. https:// doi.org/10.7763/IJSSH.2015.V5.419

Hadler, J. (2008). Sengketa Tiada Putus: Matriarkat, Reformisme Agama, dan Kolonialisme di Minangkabau. Jakarta: Freedom Institute.

Harahap, S. R. (2019). Teknik Sinematografi Dalam Menggambarkan Pesan Optimisme Melalui Film Tenggelamnya Kapal Van Der Wijck. Pena Cendikia, 1(1).

Heeren, K. Van. (2012). Contemporary Indonesian Film: Spirits of Reform and Ghost from The Past. Leiden: KITLV Press. Heide, W. van der. (2002). Malaysian Cinema, Asian Film: Border Crossings and National Cultures. Amsterdam: Amsterdam University Press.

Heider, K. G. (1991). Indonesian Cinema: National Culture on Screen. Honolulu: University of Hawaii Press.

Hoay, K. T. (1930). Melati van Agam: Produksi Paling Baru dari Tan's Film. Panorama, 182, 27-28. Retrieved from https:// jurnalfootage.net/v4/melati-van-agamproduksi-paling-baru-dari-tans-film/

Hurahmi, I. M. (2015). Tingkuluak di Nagari Koto Nan Gadang Kota Payakumbuh (Tesis). Universitas Negeri Padang, Padang. Ibrahim, A., Sati, D. D. L., Bafirman, Yanis, M., Alimunar, Ilyas, M., \& Akbar, R. (1985). Pakaian Adat Tradisional Daerah 
Sumatera Barat. Jakarta: Departemen Pendidikan dan Kebudayaan.

ica. (2009). Angkat Pencak Silat Lewat Film "Merantau." Retrieved from Entertainment JPNN.com website: https://www.jpnn. com/news/angkat-pencak-silat-lewat-filmmerantau

Iles, T. (2008). The Crisis of Identity in Contemporary Japanese Film: Personal, Cultural, National. Leiden - Boston: Brill. Indah, N. (2009). "MERANTAU” Kurang Filosofi Silat. Retrieved from KapanLagi. com website: https:/www.kapanlagi.com/ showbiz/film/indonesia/merantau-kurangfilosofi-silat.html

Ismael, S. (2007). Arsitektur Tradisional Minangkabau Nilai-nilai Budaya dalam Arsitektur Rumah Adat. Padang: Bung Hatta University Press.

Junus, U. (1984). Di Bawah Lindungan Ka'bah: Dialog Antara Film dan Novel. Masyarakat Indonesia, XI(2).

Kamal, M. (2013). "Harimau Tjampa"; Film Berlatar Minangkabau Pertama. Retrieved from Kompasiana website: https://www.kompasiana.com/ alchemist/552e1a116ea834ee3c8b456a/ harimau-tjampa-film-berlatarminangkabau-pertama

Kato, T. (1978). Change and Continuity in the Minangkabau Matrilineal System. Indonesia, 25(25), 1-16. https://doi. org/10.2307/3350964

Khamdevi, M. (2017). Studi Karakteristik Arsitektur Khas Pada Rumah Makan. Jurnal Ilmiah Penelitian MarKa, 1(1), 3338.

Kristanto, J. (2007). Katalog Film Indonesia 1926 - 2007. Jakarta: Nalar.

Lathrop, B. G., \& Sutton, D. O. (2013). Elements of mis-en-scene. Film Study Journal,
(2), 1-7. Retrieved from http://www. proseproductionsink.com/1102_Licata_ Elements_of_Mise-en-scene_modified.pdf Lewis, J. (2014). Essential Cinema: An Introduction to Film Analysis. Boston: Wadsworth.

Lukinbeal, C. (2005). Cinematic Landscapes. Journal of Cultural Geography, 23(1), 3-22.

Maresa, A. (2009). Estetika Simbolis Dalam Busana Pengantin Adat Minangkabau Di Padang. Jurnal Filsafat, 19(3), 255-272.

Marthala, A. E. (2013). Rumah Gadang: Kajian Filosofi Arsitektur Minangkabau. Bandung: Humaniora.

Miawruu. (2009). Film Merantau dan Silat Harimau. Retrieved from no world website: http://kucingtengil.blogspot.com/2009/08/ film-merantau-dan-silat-harimau.html

Mochama, A. (2020). Interpretations of Television Aesthetics: A Mise-En-Scene Analysis in Audio- Visual Coca-Cola Commercials. International Journal of Research and Scholarly Communication, 3(1), 18-37. Retrieved from https:// royalliteglobal.com/ijoras/article/view/54

Mustika, W. G., \& Budiwirman, B. (2019). Analisis Fungsi dan Makna Suntiang dalam Pakaian Adat Minangkabau. Gorga : Jurnal Seni Rupa, 8(2), 315-319. https:// doi.org/10.24114/gr.v8i2.14712

Musyafir, Lembah, G., \& Kangiden, N. (2017). Ekranisasi Novel Tenggelamnya Kapal van der Wijck ke dalam Film (Pendekatan Struktural). BAHASANTODEA, 5(2), 7684.

Nakamura, S. (2001). A Study of Regional Variations of Rumah Gadang Types in the Core of Minangkabau Area. Journal of Architecture Planning Environment, (550), 185-192. 
Navis, A. A. (1984). Alam Terkembang Jadi Guru: Adat Dan Kebudayaan Minangkabau. Jakarta: Grafiti Press.

Noviandi, F. (2013). Hanung Bramantyo: Stop Pemutaran Film Cinta Tapi Beda. Retrieved October 20, 2019, from Liputan6.com website: https://www.liputan6.com/ showbiz/read/481065/hanung-bramantyostop-pemutaran-film-cinta-tapi-beda

Oktora, N., \& Adriani, A. (2019). Studi Batik Tanah Liek Kota Padang. Gorga Jurnal Seni Rupa, 8(1), 129. https://doi.org/10.24114/ gr.v8i1.12879

Permana, R. S. M., Puspitasari, L., \& Indriani, S. S. (2019). Industri film Indonesia dalam perspektif sineas Komunitas Film Sumatera Utara. ProTVF, 3(2), 185-199. https://doi. org/10.24198/ptvf.v3i2.23667

Prasetya, L. E., \& Adi, S. M. (2011). Makna dan Filosofi Ragam Hias Pada Rumah Tradisional Minangkabau di Nagari Pariangan Tanah Datar. Seminar Nasional "Kearifan Lokal Dalam Keberagaman Untuk Pembangunan Indonesia“, 59-70. Medan: Departemen Aarsitektur, Fakultas Teknik, Universitas Sumatera Utara.

Priyambodo, A. (2018, November 13). Film Cinta Tapi Beda Diseret ke Jalur Hukum, Ada Apa? Retrieved October 20, 2019, from okecelebrity website: https://celebrity.okezone.com/ $\mathrm{read} / 2018 / 11 / 17 / 206 / 1979281 /$ film-cintatapi-beda-diseret-ke-jalur-hukum-ada-apa

Putri, J. D. (2015). Konstruksi Makna Marosok Dalam Transaksi Jual Beli Ternak di Desa Cubadak Kabupaten Tanah Datar. Jom FISIP, 2(1), 1-15. Retrieved from https:// jom.unri.ac.id/index.php/JOMFSIP/article/ view/4917

Rahman, A., Sami, Y., \& Hafiz, A. (2019). Simbol-Simbol Minangkabau dalam
Karya Seni Lukis. Serupa The Journal of Art Education, 6(1). Retrieved from http://ejournal.unp.ac.id/index.php/serupa/ article/view/8242

Ralie, S. S.C., Winandari, M.I. R., \&Handjajanti, S. (2019). Arsitektur Kontekstual di Bangunan Pusat Budaya Sumatera Barat. Prosiding Seminar Intelektual Muda \#1, Inovasi Ilmu Pengetahuan, Teknologi Dan Seni Dalam Perencanaan Dan Perancangan Lingkungan Terbangun, (April), 233-238. Jakarta.

Roberts, M. (1998). Baraka : World Cinema and the Global Culture Industry. Cinema Journal, 37(3), 62-82.

Soenarto, \& Sudyarto, S. (1983). Arsitektur Tradisional Minangkabau Selayang Pandang. Jakarta: Proyek Media Kebudayaan Direktorat Jenderal Kebudayaan Departemen Pendidikan dan Kebudayaan.

Sreekumar, J., \& Vidyapeetham, A. V. (2015). Creating Meaning through Interpretations : A Mise-En-Scene Analysis of the Film ' The Song of Sparrows .' Online Journal of Communication and Media Technologies, (Special Issue September 2015), 89-97.

Sutorini, M. P., Alif, M., \& Sarwani, S. (2019). Semiotika Gender dalam Film Brave. ProTVF, 3(1), 101-112. https://doi. org/10.24198/ptvf.v3i1.21246

Syafwandi. (1993). Arsitektur Tradisional Sumatera Barat. Jakarta: Departemen Pendidikan dan Kebudayaan.

Thalib, A. A. (2017). Isu-Isu Identitas Budaya Nasional dalam Film “ Tenggelamnya Kapal Van der Wijck ." Satwika, 1(2). Retrieved from http://ejournal.umm.ac.id/ index.php/JICC

Trisnawati,T.,\&Yesicha,C.(2018).Representasi Budaya Matrilineal Minangkabau dalam 
Film Tenggelamnya Kapal van der Wijck. Jurnal Riset Komunikasi, 1(2), 276-284. https://doi.org/10.24329/jurkom.v1i2.40

Umassari, A. R. (2018). Interaksi Simbolik dalam Proses Komunikasi Jual Beli Ternak "Marosok" di Payakumbuh Sumatera Barat. Jurnal Ilmu Komunikasi, 8(3), 258271.

Wasana, Hidayat, H. N., Immerry, T., Dahlan, F., Pramono, Meigalia, E., \& Sari, M. N. (2019). Pepatah Petitih: Its Interpretation
On Instagram. Proceeding of INCOLWIS 2019. Padang: EAI - EUDL. https://doi. org/10.4108/eai.29-8-2019.2289025

Yasmin, Setianti, Y., \& Agung, F. A. (2017). Representasi Eksploitasi Satwa dalam Film Rise of the Planets of the Apes. ProTVF, 1(2), 151-161.

Yunus, R. R., Efi, A., \& Yuliarma, Y. (2014). Studi tentang Busana Pengantin Tradisional Kurai Bukittinggi. E-Journal Home Economic and Tourism, 6(2). 